واقع بعض المهام التخصصية لأدارة الموارد البشرية في جهاز الارشاد الزراعي في محافظات المنطقة

$$
\text { الوسطى من العراق }
$$

$$
\begin{aligned}
& \text { بيان عبد الجبار رضا } \\
& \text { استاذ مساعد } \\
& \text { كلية الزراعة - جامعة بغداد - قسم الارشاد الزراعي }
\end{aligned}
$$

Eveen_91@yahoo.com

أستهدف البحث تثخيص واقع بعض المهام التخصصية لأدارة الموارد البشرية في جهاز الارشاد الزراعي، ولتحقيق أهداف

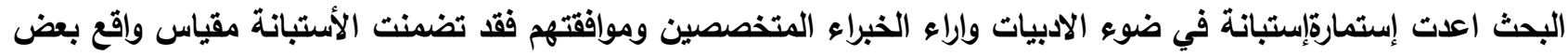
المهام التخصصية لادارة الموارد البشرية (103) فقرة توزعت على 7 محاور هي: التخطيط للموارد البشرية، الوصف الوظيفي،

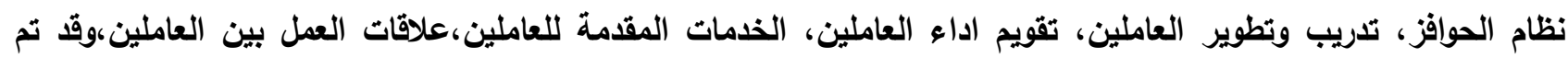
أجراء البحث على عينة عشوائية - بنسبة (50\%) من محافظات المنطقة الوسطى من العرلق وهي (بغداد وكريلاء المقدة والنجف الأثرف وواسط)، وأختيرت عينة عشوائية بنسبة (52\%) من الشعب الزراعية التابعة للمحافظات المشمولة بعينة البحث ويواقع (27) شعبة زراعية، واقتصر البحث على (166)مديراً يمثلون مدراء وحدات جهاز الارشاد الزراعي، فضلاً عن ونئه مدراء مديريات الزراعة والثعب الزراعية وادارة الموارد البشرية،وقد أظهرث نتائج البحث أن جميع الوظائف أو المهام المهام التخصصية لادارة الموارد البشرية في جهاز الارشاد الزراعي مطبقة ولكن بدرجات متفاوتة، وقد أوصت الباحثة بضرورة تبني نتائج هذا البحث من قبل جهاز الارشاد الزراعي من اجل تحسين ادارة الموارد البشرية. كلمات المفتاحية: التخطيط للموارد البشرية، التقويم للموارد البشرية، التدريب للموارد البشرية. "البحث مستل من رسالة ماجستير الباحث الاول.

The Iraqi Journal of Agricultural Sciences - 48(1): 310-324,2017

Jihad \&Ridh

\title{
THE REALITY OF SOME SPECIALIZED TASKS OF HUMAN RESOURCES MANAGEMENT IN AGRICULTURAL EXTENSION SYSTEM IN MIDDLE REGION PROVINCES OF IRAQ
}

I. S. Jihad

Researcher

B. A. Ridh

Assist. Prof.

eveen_91@yahoo.com

\section{ABSTRACT}

The research aimed to explore the reality of some specialized tasks of human resources management in agricultural extension and to reach the research aim, a questionnaire form was prepared according to specialists' opinions and their agreements. The scale questionnaire of the reality of some specialized tasks of human resources management included 103 items distributed on 7 axis: planning for human resources, occupational description, incentive system, workers training and developinge, valuation of workers performance, services provided to workers, and work relations among the workers, The research was conducted on a random sample of $50 \%$ of Iraqi middle provinces (Baghdad, Karblaa, Najaf, Wasit). A random sample about $52 \%$ of the agricultural divisions of these provinces of 27 agricultural divisions were chosen, Limitedsearch(166) managers representing units Agricultural Extension device managers, as well as the directors of the departmentsof agricultureand agriculturalpeople andthe management of humanresources, Results showed that all specialized occupations or tasks of human resources management in agricultural extension system were applied, but in different degrees, The researcher recommended the necessity of adopting this research by agricultural extension system to improve the management of human resources.

Key words: human resource planning, Calendar for human resources, training and human resources *Part of M.Sc.thesis of the first author. 
للمنظمات العاملة بأختلاف أنواعها ، عن طريق العناصر

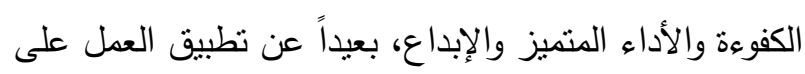
أساس إسقاط الفرض.اصبح عامل الزمن من العوامل الرئيسة

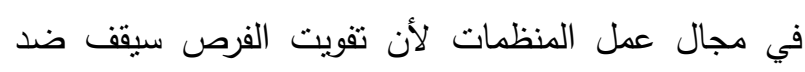
تطوير العمل وتقدمه ، وأن إحراز النجاح دفع تلك المنظمات

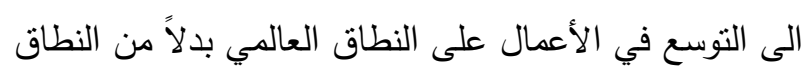

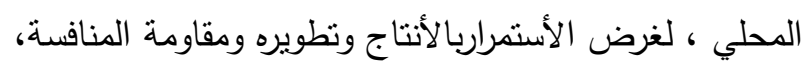

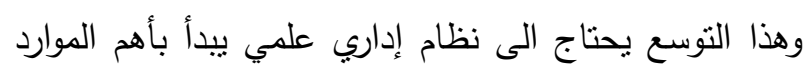

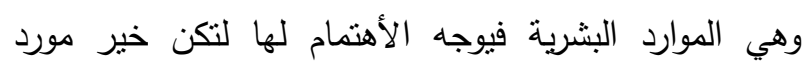
للمنظمة في مسيرة العمل والمنافسة (16)،لذاتعد أدارة الموارد البثرية احدى المقومات الاساس لنجاح المنظمة بل يمكن

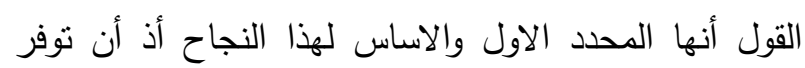
قوى عاملة ذات كفاءة ومسؤولية تمكنها من النهوض بأعباء العمل وتحقيق اهداف المنظمة واستخدام امكانياتها المادية المتاحة بأكبر كفاءة ممكنة (12)، وتتفق وجهات نظر العناف

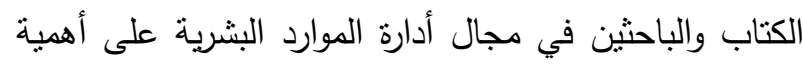

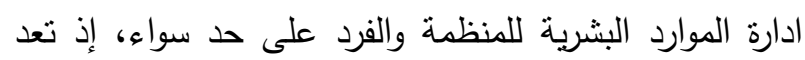
من أهم وظائف المنظمات من حيث رأس المال البشري والمعرفي وهو اساس ميزتها التتافسية في ميدان الاعمال

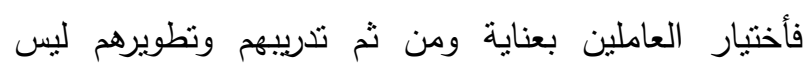
بالمهمة السهلة او السريعة ، كذلك فأن تقييم ادائهم وتحفيزهم

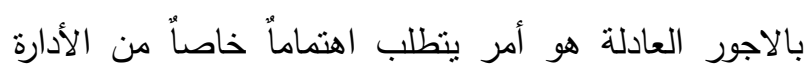
المسؤولة عن الموارد البشرية (8)،وفي هذا الصدد أنشار

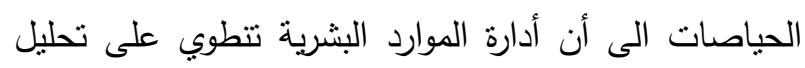

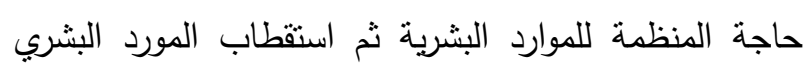

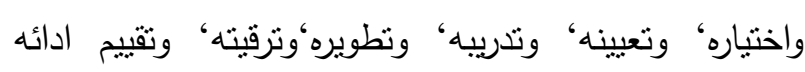

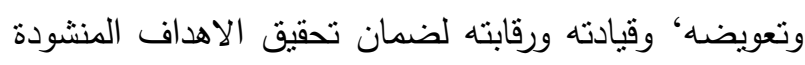

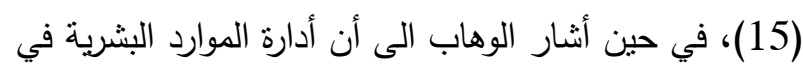

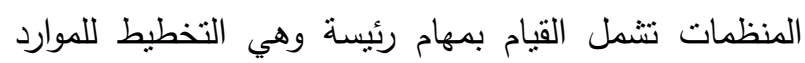

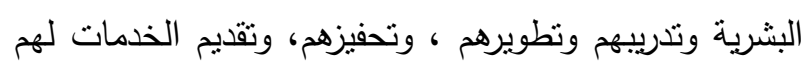

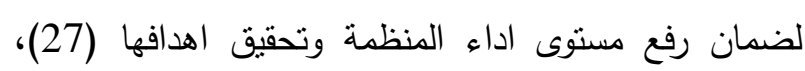

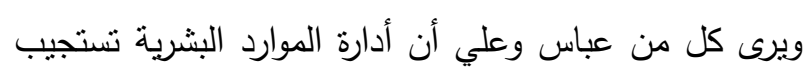

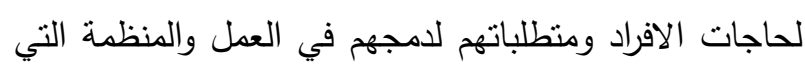
يعمون فيها وليأخذوا دورهم في أدارة وتوجيه الموارد المتاحة

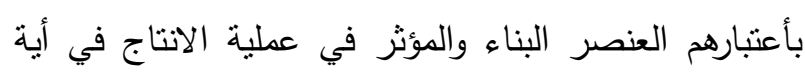
منظمة (4)، وأوضح عبد القادر وأبوسن في دراستهما الى فئل
المقدمة

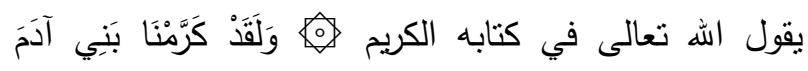

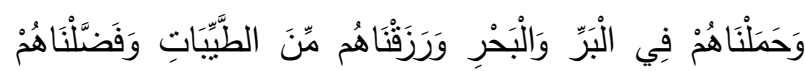

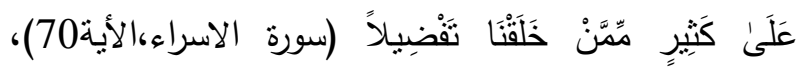

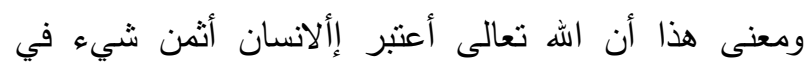

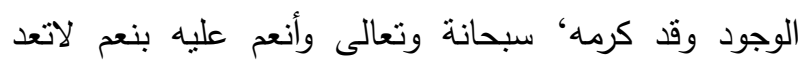

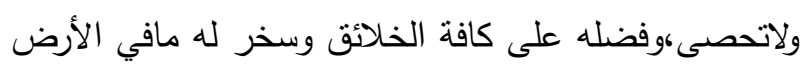

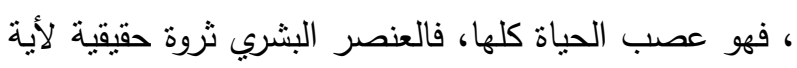
أمة من الأمم، إذ يعد من العناصر الأكثر أهمية في التتمية

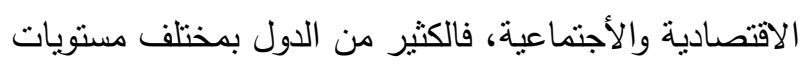

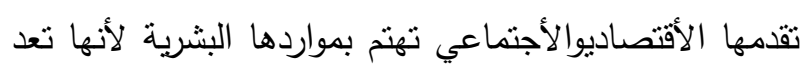

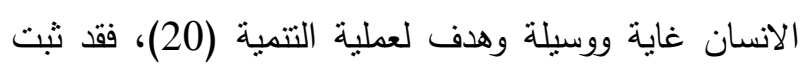

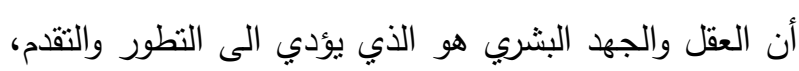

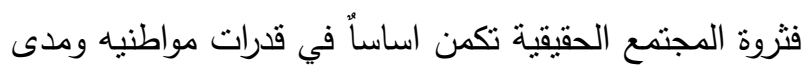
ادراكهم وقدراتهم العلميه (1)، واصبحت الموارد البشرية أحد

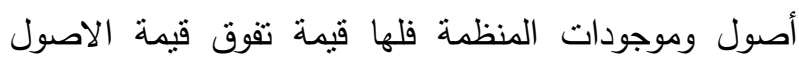
الاخرى المادية، إذ لايمكن تحقيق اهداف المنظمة بدون

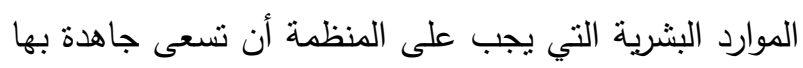

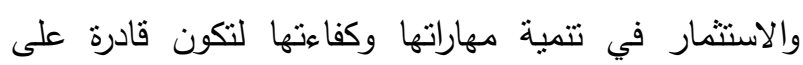
تحقيق اهداف المنظمة بفعالية (24)، إذ أشار عقيلي أن قوة الموارد البشرية وفاعلية أدائها، تعني قوة المنظمة وقدالية الهدرتها

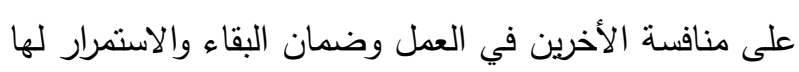
(5)، فالعنصر البشري بما لديه من قدرة على التجديد

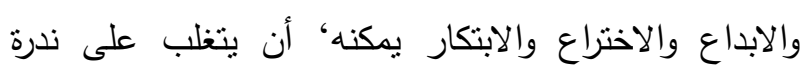

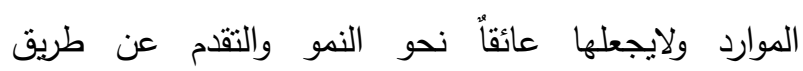

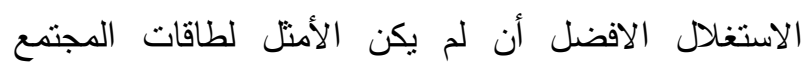

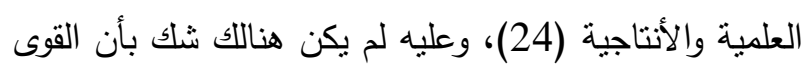
البشرية هي الدعامة الاولى للأقتصاد الوطني والقومي وتتظيم

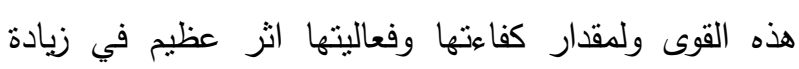
الطاقة الانتاجية ورفع مسنوى أداء المنظمة (10)،ونظراً لأهمية الموارد البشرية نشأعلم مختص يهتم بأدارتها وتطويرها

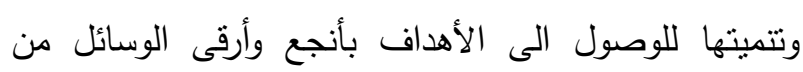

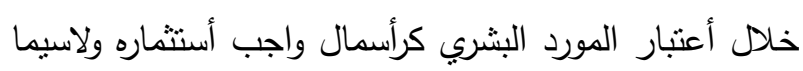

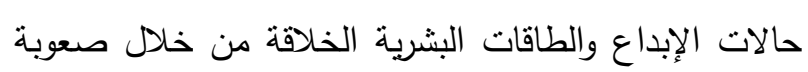

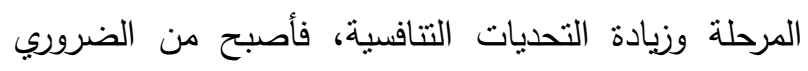
إيجاد الطاقات البشرية التي نتارك في نقلة النجاح النوعي 
(11)، وأنشار قمر الى أن المنظمات الارشادية في الدول النامية ولاسيما في العراق تواجه مشكلات رئيسة نتمنل في قلة الكفاءة المهنية ونقص الحماس بين موظفيها (19)، كما أثنار كل من عطا والبدري الى أن كفاءة جهاز الأرشاد

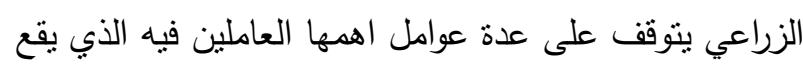

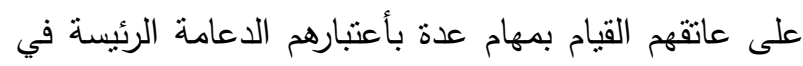

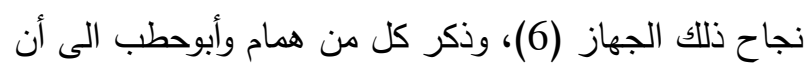

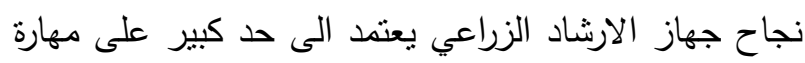

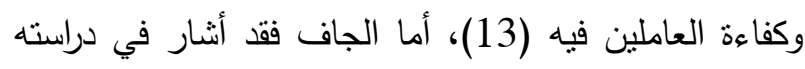
الى أن مستوى اداء الموظفين الزراعيين المكلفين بالأعمال

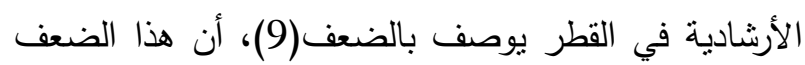

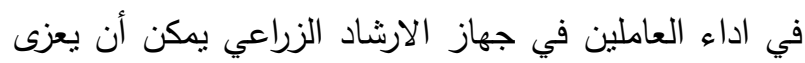

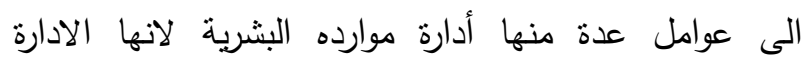

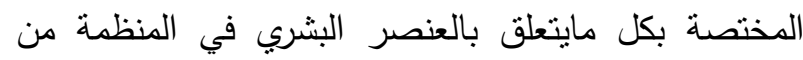

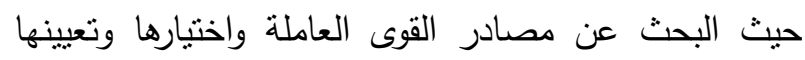
وتدريبها وتهيئة المناخ الملائم الذي يدفع العاملين الى بذل التل جهود مستمرة لتحقيق اهداف المنظمة (14)، إذ أن توسيع نطاق نطبيق ممارسات أدارة الموارد البشرية في التتظيمات يؤدي الى تطوير ورفع كفاءة العاملين الى جانب نطوير

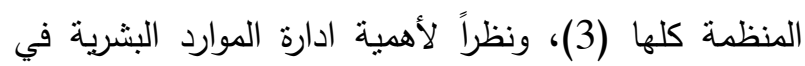

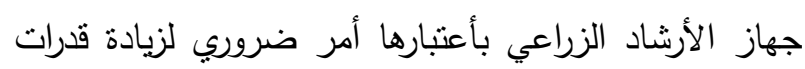

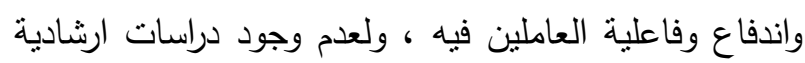

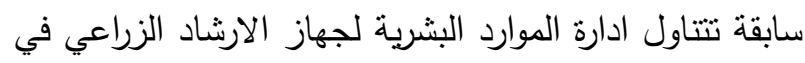
العراق، لذا جاء هذا البحث ليجيب على النساؤل الأتي:

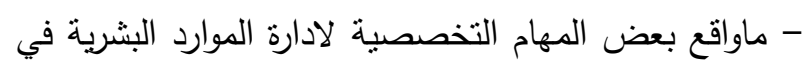

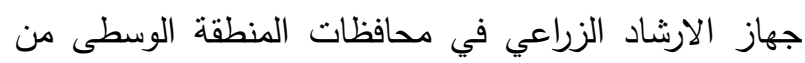

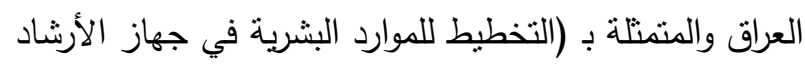
الزراعي والوصف الوظيفي ونظام الحوافز وتدريب وتطوير العاملين وتقويم اداء العاملين والخدمات المقدمة للعاملين وعلاقات العمل بين العاملين) ؟

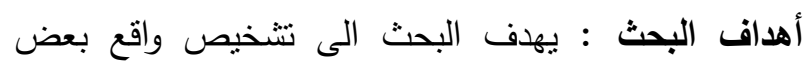
المهام التخصصية لادارة الموارد البشرية في جهاز الارشاد البحث لهاد الزراعي في محافظات المنطقة الوسطى من العراق من خلال

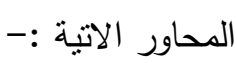
1-التخطيط للموارد البشرية. 2-الوصف الوظيفي.
وجود علاقة ايجابية بين ممارسات أدارة الموارد البشرية

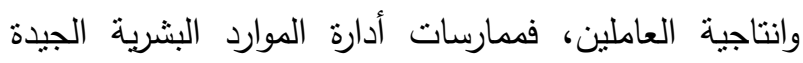
تتعكس ايجاباً على انتاجية العاملين (18)، وتوصل كل من من النهات فوطة والقطب في دراستهما الى أن تطبيق ممارسات أدارة الموارد البشرية في المصارف والمتمنلة بـ(التحليل الوظيفي ،تخطيط الموارد البشرية ،التوظيف،التدريب والتطوير ،أدارة

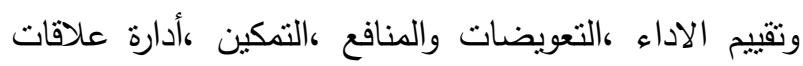

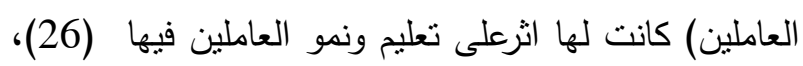
وأما جواد وفوطة فتوصلا في دراستهما الى أن التخطيط للموارد البشرية له، اثر واضح على ربحية الثركات المساهمة فورها العامة في الاردن وعلى القيمة السوقية المضافة لها (17)، وتوصلت الرديني في دراستها الى أن ممارسات استراتيجية التدريب نؤدي الى تحسين اداء العاملين في المنظمة (23)، وأوضح أبو شرخ أن علاقات التقدير والاحترام المنبادل بين الزملاء في العمل تساهم في تعزيز مبادىه الاخاء والتعاون بين موظفيها وتتجع على تتمية وتهيئة بيئة عمل نسودها

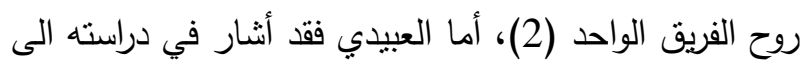

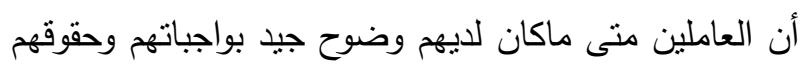
الوظيفية شعروا بمتعة في تتفيذ العمل (21)،ويعد جهاز لوناز

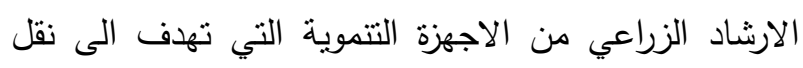

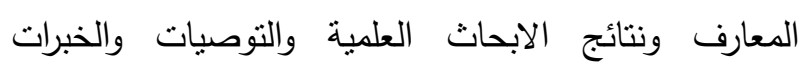
والأفكار الزراعية المستحدثة بطريقة مبسطة ومفهومة للسكان

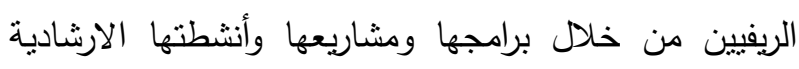
الزراعية لغرض زيادة انتاجهم الزراعي وتحسين حالتهم

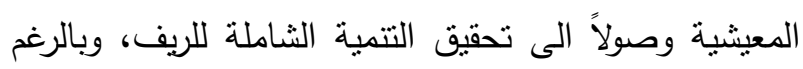

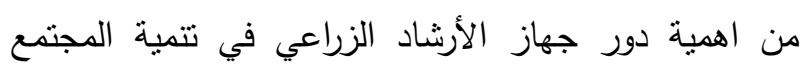

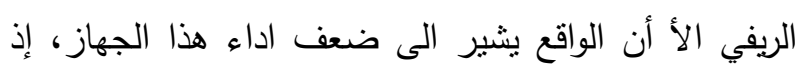

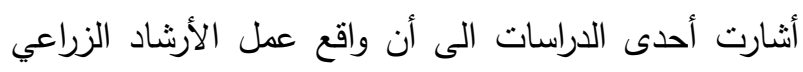
في العراق يوصف بالضعف في مقابلة الاهداف المنشودة (11)، كما اثارت دراسة أخرى الى أن الوظائف والعمليات

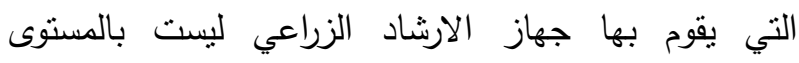
المطلوب (25)، ويمكن أن يعزى هذا الضعف في اداء جهاز الارشاد الزراعي الى عدة عوامل منها ضعف اداء إداء العاملين فيه، إذ أثنارت دراسة الفريجي الى أن ضعف الزفاعي مستوى فاعلية

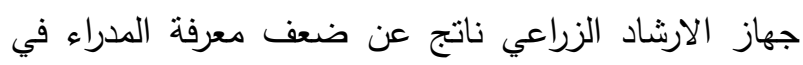
مجال ادارة وحداتهم الارشادية وادارة برامجها الارشادية 
4-العاملون في الثعب الزراعية (روؤساء الثعب الزراعية ووكلائهم ،مسؤول وحدة الارشاد الزراعي ،مسؤول وحدة أدارة الموارد البشرية) التابعة لمديريات الزراعة في محافظات الانطات لردي المنطقة الوسطى. - المورد.

5-مدراء المراكز التدريبية ومعاونيهم في محافظات المنطقة الوسطى.

6- مسؤولوا المزارع الارشادية التابعة للمراكز الارشادية التدريبية في محافظات المنطقة الوسطى.

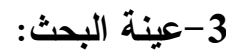

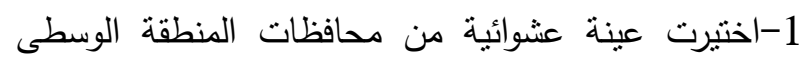
بنسبة\% 50\% على أن تكون محافظة بغداد التي فيهادائرة

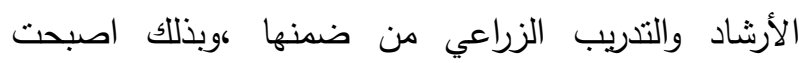

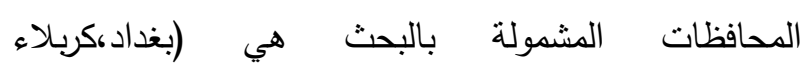
المقسة،النجف الأتشرف،واسط).

2-اختيرت عينة عشوائية بنسبة 52\% من الثعب الزراعية التابعة للمحافظات المشموله بالبحث والبالغ عددها 51 شعبة

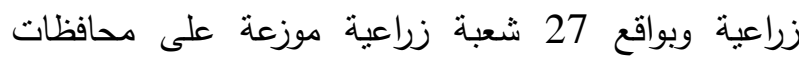
(بغداد ،كربلاء المقدسة ،النجف الأشرف ،واسط). 3- جميع رؤوساء الاقسام الفنية والادارية في دائرة الارشاد الجاء الترف

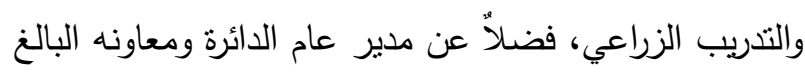
عددهم 18 مبحوثاً. 4- جميع مدراء المراكز التدريبية الارشادية ومعاونيهم التابعين لدائرة الارشاد والتدريب الزراعي في المحافظات المشمولة بعينة البحث والبالغ عددهم 8 مبحوثين .

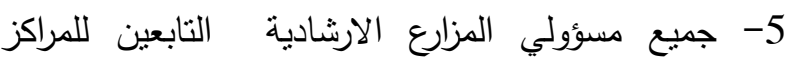
التدريبية الارشادية في المحافظات المشمولة بعينة البحث والبالغ عددهم 16 مبحوثناً. 6- جميع مدراء مديريات الزراعة في المحافظات المشمولة

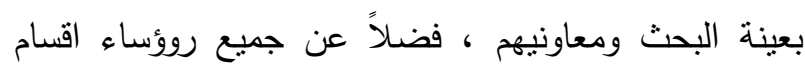

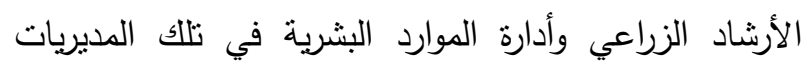

$$
\text { والبالغ عددهم } 16 \text { مبحوثاً. }
$$

7- جميع روؤساء الثعب الزراعية ووكلائهم ومسؤولي وحدات الارشاد الزراعي وأدارة الموارد البشرية في المحافظات لزعاء ولهاء

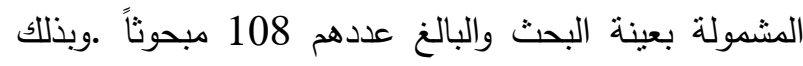
اصبح العدد الكلي لعينة البحث 166 كما موضح في الجدول

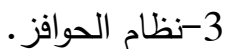
4-تدريب وتطوير العاملين.

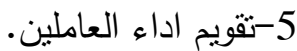
6-الخدمات المقدمة للعاملين. 7-علاقات العمل بين العاملين. فرضية البحث: يوجد ضعف في بعض المهام التخصصية لأدارة الموارد البشرية في جهاز الارشاد الزراعي في محافات المنطقة الوسطى من العراق والمتمثلة بـ : 1-التخطيط للموارد البشرية. 2-الوصف الوظيفي.

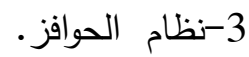
4-تدريب وتطوير العاملين. 5-تقويم اداء العاملين. 6-الخدمات المقدمة للعاملين. 7-علاقات العمل بين العاملين. مواد وطرائق البحث 1-منهجية البحث: من أجل تحقيق أهداف البحث أستخدم المنهج الوصفي الذي يعد احد طرائق البحث التي تنتاول

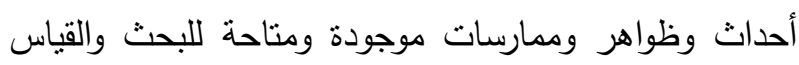
كما هي دون تدخل الباحث في مجرياتها، ويستطيع الباحث

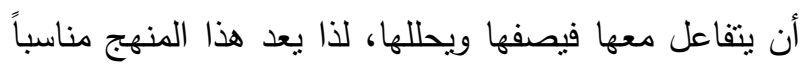
لللتوصل الى بيانات وحقائق تفصيلية عن (واقع بعض المهام

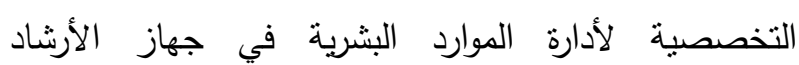
الزراعي). 2-مجتمع البحث : يشتمل مجتمع البحث على الأتي :1-محافظات المنطقة الوسطى من العراق والبالغ عددها8

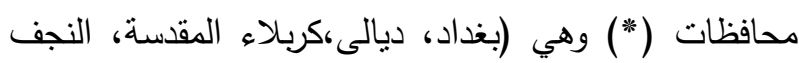
الاشرف، واسط، الانبار ، صلاح الدين، بابل).

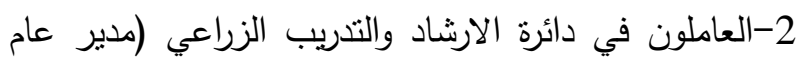
،معاون مدير عام ، رؤوساء الاقسام الفنية والادارية في

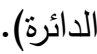
3-العاملون في مديريات الزراعة (مدراء مديريات الزراعة ومعاونيهم، رؤوساء اقسام الارشاد الزراعي،رؤوساء اقسام أدارة الموارد البشرية ) في محافظات المنطقة الوسطى . 
جدول 1. توزيع عينة البحث

\begin{tabular}{|c|c|c|c|c|c|c|c|c|c|c|c|c|}
\hline \multirow[b]{2}{*}{ المواتولي البشودية } & \multicolumn{3}{|c|}{ الثبب الزراعية } & \multicolumn{4}{|c|}{ مديريات الزراعة } & \multicolumn{4}{|c|}{ دائرة الارشاد والتدريب الزراعي } & \multirow[b]{2}{*}{ المحافظات } \\
\hline & مسؤول & وروكلائهب & 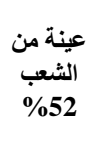 & الزراعبة & الدارة المواءرد اقدسام & الارشسام & ومعاونيريات & الارشزارية & والارشادرية & رؤساء & والعائم & \\
\hline 9 & 9 & 18 & 9 & 17 & $\mathbf{1}$ & 1 & 2 & 2 & 2 & 16 & 2 & 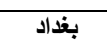 \\
\hline 4 & 4 & 8 & 4 & 8 & 1 & 1 & 2 & 6 & 2 & & & كربلاءة \\
\hline 5 & 5 & 10 & 5 & 9 & 1 & 1 & 2 & 4 & 2 & & & الاشنف \\
\hline 9 & 9 & 18 & 9 & 17 & 1 & 1 & 2 & 4 & 2 & & & الكوت \\
\hline 27 & 27 & 54 & 27 & 51 & $\begin{array}{ll}4 & \\
& \end{array}$ & لعينة الـ & المجموع (ال & 16 & 8 & 16 & 2 & المجموع \\
\hline
\end{tabular}

الخبراء هو لفحص الصدق الظاهري وصدق المحتوى له'،

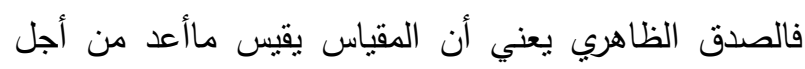
قياسه فعلاً، اي يقيس الظاهرة التي أعد لقياسها ولايقيس شئئًاً

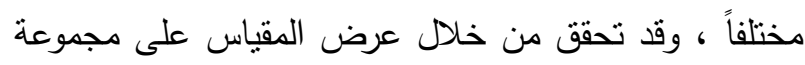

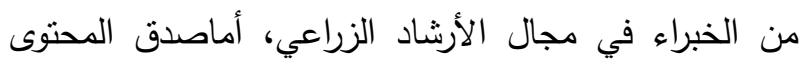
يعني فحص مضمون اومحتوى الاختبار فحصاً دقيقاً منتظماً لغرض تحديد ما اذا كان يشتمل على عينة ممنلة لميدان

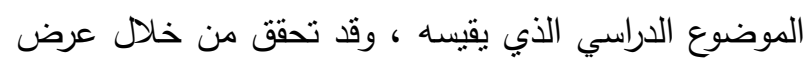
المقياس على مجموعة من الخبراء المتخصصين في مجال

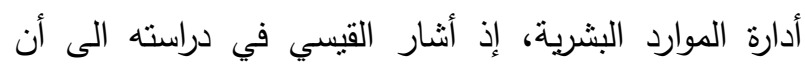

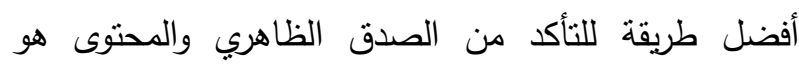
عرض الاداة على مجموعة من المحكمين وتقديرهم مدى تحقق الصفة المراد قياسها. ثالثاً:تحديد معيار موافقة الخبراء (عتبة القطع )على محاور وفقرات المقياس:أذ يعد المعيار أوعنبة القطع اساساً للحكم

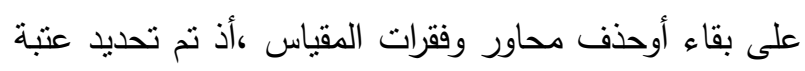
القطع بنسبة 75\% فأكثر في درجة موافقة الخبراء لبقاء اي

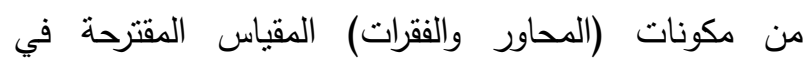
صيغتها النهائية، إذ ذكر المغربي أن معامل صدق الأداة يعد

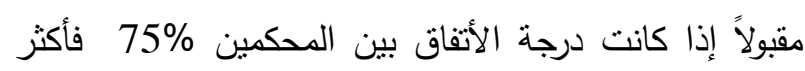

رابعاً:حساب متوسطات درجات موافقة الخبراء على مكونات

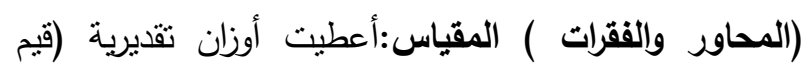

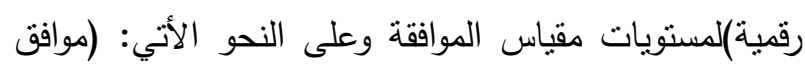

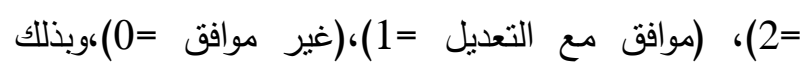
تراوحت درجة المقياس بين 0-2درجة، واحتسبت المتوسطات بحساب مجموع الدرجات المتحصل عليها على عدد الخبراء.
4-بناء المقياس :-اولا-اعداد المقياس بصورته الاولية :

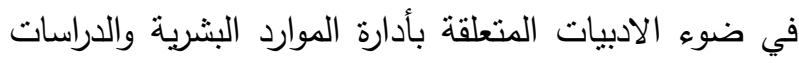

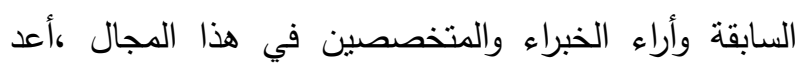
مقياس واقع بعض المهام التخصصية لادارة الموارد البشرية بصورته الأولية والمتكون من سبعة محاور وهي (التخطيط

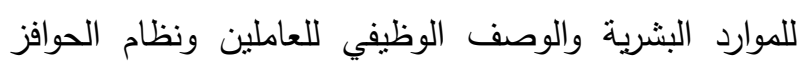
وتدريب وتطوير العاملين وتقويم اداء العاملين والخدمات

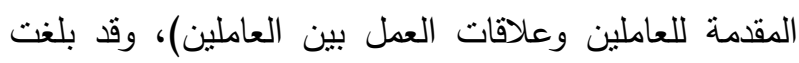

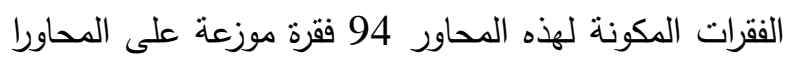

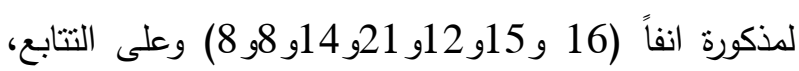
2. وكما موضح في جدول جدول 2. توزيع المحاور والفقرات المقترحة لمقياس واقع بعض المهام التخصصية لأدارة المواردالبشرية في جهاز

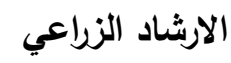

\begin{tabular}{|c|c|c|c|}
\hline$\%$ & عدد الفقرات & المحاور & 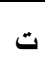 \\
\hline 17.02 & 16 & التخطيط للموارد البشرية & $\mathbf{1}$ \\
\hline 15.96 & 15 & الوصف الوظيفي & 2 \\
\hline 12.77 & 12 & نظام الحواف & 3 \\
\hline 22.34 & 21 & تدريب وتطوير العاملين & 4 \\
\hline 14.89 & 14 & تقويم اداء العاملين & 5 \\
\hline 8.51 & 8 & الخدمات المقدمة للعاملين & 6 \\
\hline 8.51 & 8 & علاقات العمل بين العاملين & 7 \\
\hline 100 & 94 & 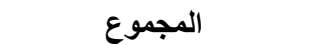 & \\
\hline
\end{tabular}

ثانياً:تظوير المقياس (عرض المحاور والفقرات على الخبراء المتخصصين) عرضت المحاور والفقرات بصورتها الأولية

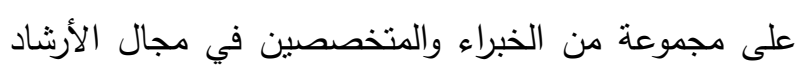
الزراعي وادارة الموارد البشرية والبالغ عددهم 23 خبيراً بوساطة أستخدام أستمارة أستبانة لبيان درجة موافقتهم على لئل

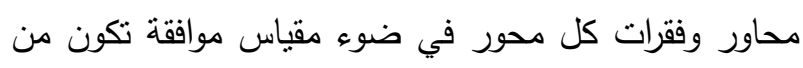
ثلاثة مستويات هي : موافق وموافق مع التعديل وغير موافق

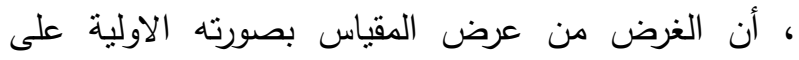


لوحدات أدارة الموارد البشرية التابعة للشعب الزراعية المشمولة بالعينة ، ومدير المركز التدريبي الارشادي، و $50 \%$ من مسؤولي المزارع الارشادية البالغ عددهم 8 مسؤولين

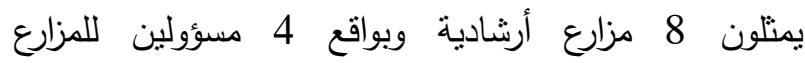

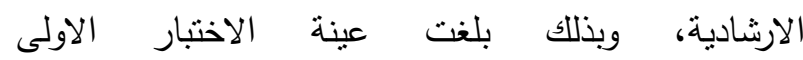
29مبحوثاً.واستخدم لقياس ثبات مقياس واقع بعض المض المهام

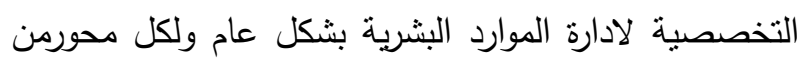

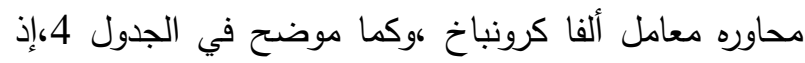
يعد معامل ألفا كرونباخ واحد من اختبارات الإحصائية المهمة

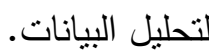
جدول 4.قيم معامل ألفا كرونباخ لمقياس واقع بعض المهام

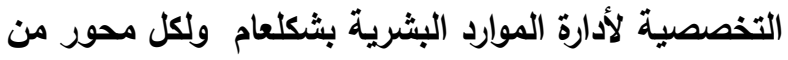

\begin{tabular}{|c|c|c|}
\hline قيم معامل ألفا & المقياس & 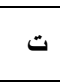 \\
\hline 0.92 & واقع بعض المهام التخصصية لأدارة & 1 \\
\hline 0.89 & التخطيط للموارد البشرية & 1-1 \\
\hline 0.91 & الوصف الوظيفي . & $2-1$ \\
\hline 0.85 & نظام الحوافز. & 3-1 \\
\hline 0.94 & تدريب وتظوير العاملين . & 4-1 \\
\hline 0.96 & تقويم اداء العاملين . & $5-1$ \\
\hline 0.95 & الخذمات المقدمة للعاملين . & 6-1 \\
\hline 0.90 & علاقات العمل بين العاملين. & $7-1$ \\
\hline
\end{tabular}

يتضح من الجدول اعلاه، أن قيم معامل الثبات لمقياس واقع

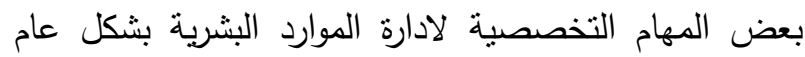

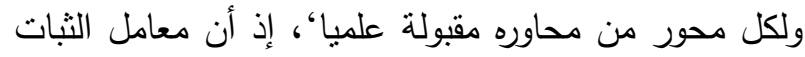

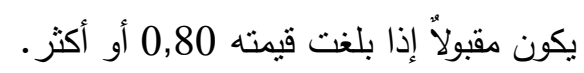

7-جمع البيانات:جمعت بيانات البحث من خلال استمارة أستبانة وبطريقة المقابلة الثخصية مع المبحوثين خلال المدة 2014/9/28 - 2014/12/25من العينة البالغ

$$
\text { عددها } 166 \text { مبحوثاً. }
$$

\section{8-الوسائل الاحصائية المستخدمة:}

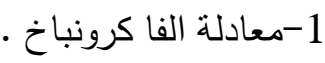

2-الوسط المرجح. 3-الوزن المئوي.

\section{النتائج والمناقشة}

1-محور التخطيط للموارد البشرية في جهاز الأرشاد الزراعي حصلت الفقرات المتعلقة بمحور (التخطيط للموارد

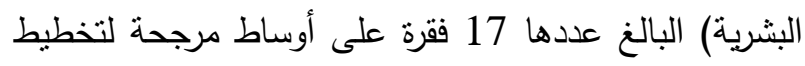
الموارد البشرية تقع بين 4 - 3.264 درجة ، وأوزان مئوية
خامساُ:إعداد المقياس بصورته النهائية (وضع المحاور والفقرات بصورتها النهائية):في ضوء مقارنة متوسطات

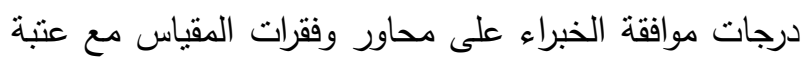
القطع لإعداد المقياس بصورته النهائية ،فقد حققت جميع المحاور والفقرات عتبة القطع فأكثر إذ بلغت عنبة القطع لمقياس واقع بعض المهام التخصصية لأدارة الموارد البشرية

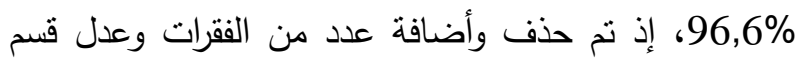
منها ، فضلاً عن دمج بعض الفقرات المتشابهة وفصلها كوبذلك اصبحت عدد فقرات المقياس 103 فقرة موزعة على بعلى 7محاور كما موضح في جدول 3. جدول 3. توزيع المحاور والفقرات المقترحة لمقياس واقع دولع بعض المهام التخصصية لأدارة الموارد البشرية في جهاز

\begin{tabular}{|c|c|c|c|}
\hline & عدد الفقرات & المحاور & 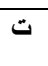 \\
\hline 16.50 & 17 & التخطيط للموارد البشرية . & 1 \\
\hline 14.56 & 15 & الوصف الوظيفي & 2 \\
\hline 9.71 & 10 & نظام الحوافز & 3 \\
\hline 21.36 & 22 & تدريب وتظوير العاملين . & 4 \\
\hline 16.50 & 17 & تقويم اداء العاملين . & 5 \\
\hline 11.65 & 12 & الخدمات المقدمة للعاملين & 6 \\
\hline 9.71 & 10 & علاقات العمل بين العاملين & 7 \\
\hline 100 & 103 & المجموع & \\
\hline
\end{tabular}
الارشاد الزراعي في صورته النهائية

5-اداة البحث :أعدت استمارة البحث كأداة لجمع البيانات المتعلقة بواقع بعض المهام التخصصية لأدارة الموارد البشرية

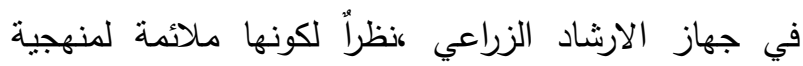
البحث المتبعة،أذ تعد ألاستبانة من أكثر الوسائل استخداماً لجمع البيانات اوالحقائق التي تتعلق باراء عدد معين من الأفراد. 6-قياس الثبات:الثبات يعني درجة الاستقرار فيما يتحقق من أداة القياس مع الزمن، أي أن الاداة تعطي نتائج متقاربة أو دأن

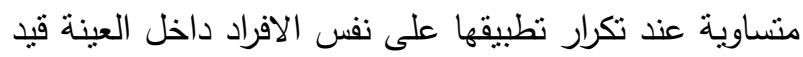

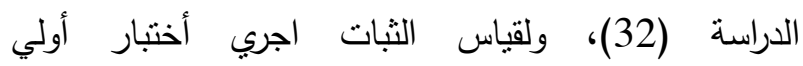
للأستبانةpre-test في شهر أب2014)، ولى على عينة عشوائية من المبحوثين في محافظة بابل والمؤلفة من مدير مديرية زراعة بابل، رئيس قسم الأرشاد الزراعي في مديرية زراعة

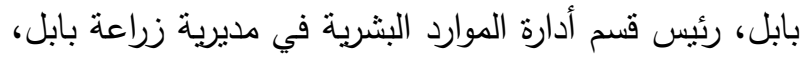
و (50\%) من رؤوساء الثعب الزراعية التابعة لمديرية زراعة مدئه بابل والبالغ عددهم (14) رئيساً يمنلون (14) شعبة زراعية

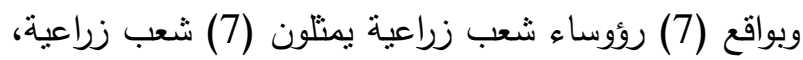

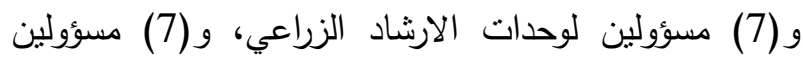


الزراعي لكونها حصلت على أوساط مرجحة اكبر من الوسط

تقع بين 80 - 65.28 درجة ، كما موضح في الجدول 5، الفرضي $\quad 3 \quad$ ل 3

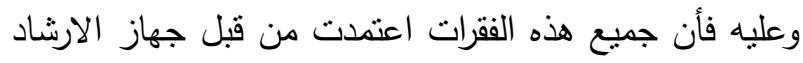

جدول 5. توزيع المبحوثين وفقا لققرات محور التخطيط للموارد البشرية

\begin{tabular}{|c|c|c|c|c|}
\hline الترتيب & 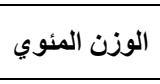 & 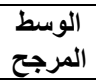 & الفقرات & رقم الفقرة في \\
\hline 1 & 80 & 4 & 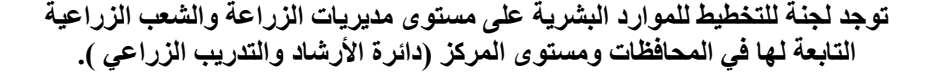 & 11 \\
\hline 2 & 79.62 & 3.981 & 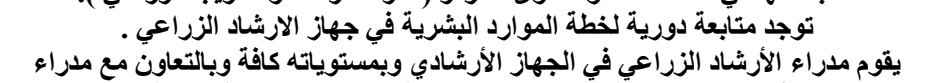 & 17 \\
\hline 3 & 79.42 & 3.971 & 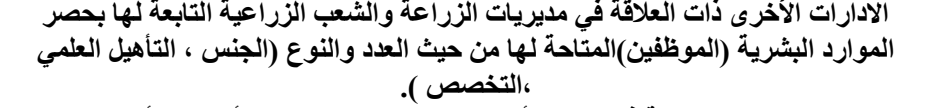 & 13 \\
\hline 4 & 77.78 & 3.889 & 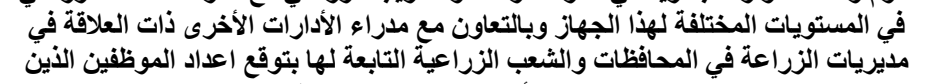 & 12 \\
\hline 5 & 75.44 & 3.772 & 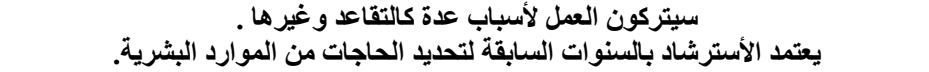 & 7 \\
\hline 6 & 74.02 & 3.701 & تحديد الاموال المطلوبة لتنا & 14 \\
\hline 7 & 68.9 & 3.445 & يعتمد تحديد الحاجات من الموارد البشرية على علد النشاطات والخدمات الأرشادية المتوقع . لمجيفي & 8 \\
\hline 8 & 68.24 & 3.412 & 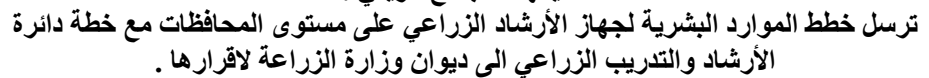 & 16 \\
\hline 9 & 67.56 & 3.378 & 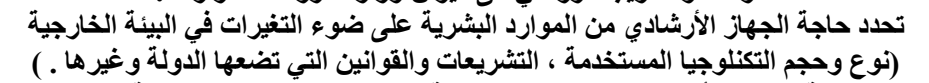 & 9 \\
\hline 10 & 67.06 & 3.353 & 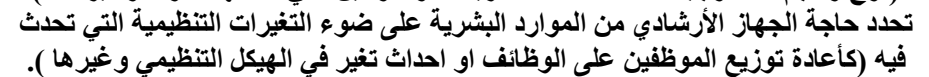 & 10 \\
\hline 11 & 66.42 & 3.321 & أُن الاهداف المحددة للتخطيط للموارد البشرية هي مايعول علَيه عذد أجراء هذه العملية . & 3 \\
\hline 12 & 66.36 & 3.318 & توجد في الدائرة قاعدة بيانات للموارد البشرية في جهاز الأرشاد الزراعي تعتمد عليها عند التهوارد. & 6 \\
\hline 13 & 66.2 & 3.310 & يتم تحديد الحاجات المستقبلية من الموارد البشرية لجهاز الأرشاد الزراعي من حيث الكم & 4 \\
\hline 14 & 66.02 & 3.301 & توجد أهداف واضحة ومحدة للتخطيط للموارد البشرية في جهاز الأرشاد الزراعي . & 2 \\
\hline 15 & 65.96 & 3.298 & أن مفهوم تخطيط الموارد البشرية واضحة لاى جميع المسؤولين عند التخطيط للموارد & 1 \\
\hline 16 & 65.54 & 3.277 & 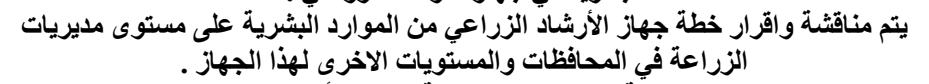 & 15 \\
\hline 17 & 65.28 & 3.264 & 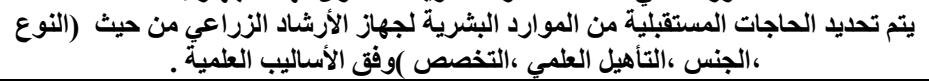 & 5 \\
\hline
\end{tabular}

لها الاهمية والقيمة تفوق القرارات الفردية. أما فقرة (يتم تحديد الحاجات المستقبلية من الموارد البشرية لجهاز الأرشاد الزراعي من حيث النوع (الجنس والتأهيل العلمي والتخصص) وفق الأساليب العلمية) فقد جاءت بالمرتبة الأخيرة بوسط مرجح 3.264 درجة، ووزن مئوي 65.28 درجة، وقد يعزى السبب في ذلك الى قلة اهتمام ووعي القائمين بعملية التخطيط للموارد البشرية في تحديد الحاجات المستقبلية للموارد البثرية من حيث النوع (الجنس والتأهيل العلمي والتخصص) بشكل يتلائم مع منطلبات العمل، كما وقد يعزى السبب في ذلك الى شعور القائمين بعملية التخطيط للموارد البشرية في جهاز الارشاد الزراعي بعدم أو قلة جدوى تحديد الحاجات المسثقبلية من الموارد البشرية من حيث النوع لكون اغلب التعيينات في جهاز الارشاد الزراعي تتم من قبل وزارة
وبصدد نرنيب الفقرات المتعلقة بمحور (التخطبط للموارد البشرية) يتضح من الجدول 5 تقارب بين الأوساط المرجحة للفقرات المتعلقة بهذا المحور، ومع ذلك جاءت فقرة (توجد لجنة لتخطيط الموارد البشرية على مستوى مديريات الزراعة والشعب الزراعية التابعة لها في المحافظات ومستوى المركز (دائرة الأرثاد والتدريب الزراعي )) بالترتيب الأول بوسط مرجح 4 درجة، ووزن مئوي 80 درجة، وقد يعزى السبب في ذللك الى الاهتمام العالي من قبل جهاز الارشاد الزراعي بضرورة وجود لجنة لتخطيط الموارد البشرية تسعى الى رفع كفاءة وفاعلية جهاز الارشاد الزراعي من خلال تحديد الطاقات البشرية القادرة على الابداع والتببؤ واتخاذ القرارات لاحداث التغيير والتطور في العمل الارشادي، فضلا عن ان القرارات والمشورات الجماعية التي تتخذها اللجان التخطيطية 
(الوصف الوظيفي) البالغ عددها 15 فقرة على أوساط مرجحة للوصف الوظيفي تقع بين 3.581- 3درجة، وأوزان مئوية تقع بين 71.62-60 درجة، كما موضح في الجدول 6، وعليه فأن جميع هذه الفقرات اعتمدت من قبل جهات دهاز الارشاد الزراعي لكونها حصلت على أوساط مرجحة اكبر من هن هند الوسط الفرضي للمقياس البالغ 3 درجات.
الزراعة على ضوء الكم (العدد) المطلوب من الموارد البشرية

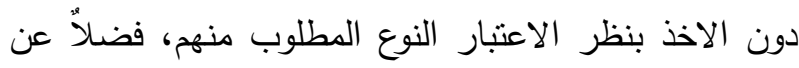

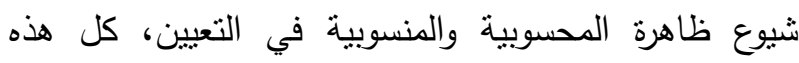
الامور أدت الى حصول هذه الفقرة على المرتبة الاخيرة من

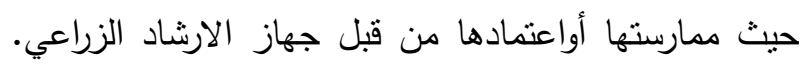
2-محور الوصف الوظيفي:حصلت الفقرات المتعلقة بمحور الأناد الزران جدول 6 :توزيع المبحوثين وفقاً لفقرات محور الوصف الوظيفي

\begin{tabular}{|c|c|c|c|c|}
\hline الترتيب & الوزن المئوي & 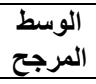 & 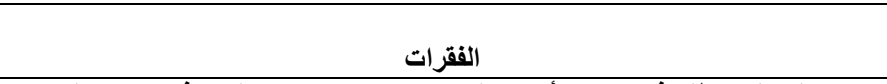 & رقم الأستمرة في \\
\hline 1 & 71.62 & 3.581 & يعرف كل موظف في جهاز الأرشاد الزراعي واجباته ومسؤولياته في اداء عمله . & 2 \\
\hline 2 & 71.5 & $\mathbf{3 . 5 7 5}$ & يحدد الوصفت الوظيفي الواجبات والتمسؤوليات اللازمة لكل وظظيفة. & 6 \\
\hline 3 & 70.44 & 3.522 & 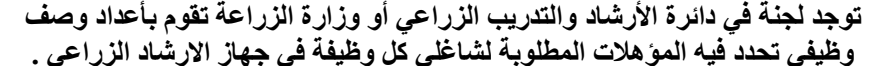 & 9 \\
\hline 4 & 69.82 & 3.491 & 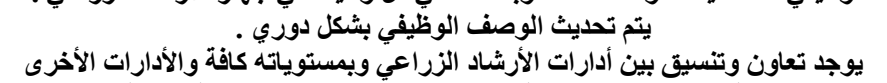 & 15 \\
\hline 5 & 69.76 & 3.488 & ذات العلاقة في مديريات الزراعة في المحافظات والثعب الزراعية التابعة لها عند & 13 \\
\hline 6 & 68.62 & 3.341 & عند وصف الوظائف تحدد المؤهلات المطلوبة لثاغلي كل وظيفة في جهاز الأرشاد & 7 \\
\hline 7 & 66.58 & 3.329 & يوجد توصيف وظيفي واضح ومحدد بدليل لكل وظيً & 1 \\
\hline 8 & 64.86 & 3.243 & يتم وصف الوظتِفة كما يراد لها أن تكر & 12 \\
\hline 9 & 64.22 & 3.211 & 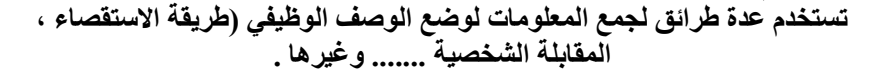 & 11 \\
\hline 10 & 63.42 & 3.171 & 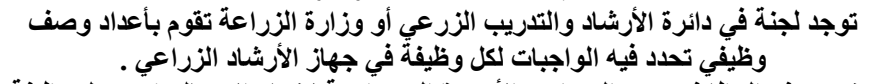 & 10 \\
\hline 11 & 62.26 & 3.113 & عند وصف الوظائَف تحدد المعدات والأجهزة المستخدمة لانجاز الاعمال ضمن كل وظيفة & 4 \\
\hline 12 & 61.96 & 3.098 & يصادق (يقر)التوصيف الوظيفي من قبل الأدارة العليا في دائرة الأرشاد والتدريب & 14 \\
\hline 13 & 61 & 3.05 & عند وصف الوظائف تحدد الوقت والمجهود الفكري والبدني اللازم لانهاء العمل داخل كل & 5 \\
\hline 14 & 60.22 & 3.011 & 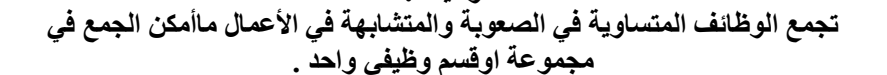 & 8 \\
\hline 15 & 60 & 3 & عند وصف الوظائف تحدد ظروف العمل المحيطة لكل وظيفة (حرارة ، برودة ، ضوضاء & 3 \\
\hline
\end{tabular}

وصف الوظائف تحدد ظروف العمل المحيطة لكل وظيفة (حرارة 6برودة ،ضوضاء .......) فقد جاءت بالمرتبة الأخيرة بوسط مرجح 3 درجات ، ووزن مئوي 60 درجة، وقد ويعزى برد السبب في ذلك الى قلة أوعدم توفر المستلزمات أوالامكانيات اللازمة لتهيئة ظروف العمل المحيطة بكل وظيفة في جهاز

$$
\text { الارشاد الزراعي. }
$$

3-محور نظام الحوافز حصلت الفقرات المتعلقة بمحور (نظام الحوافز) البالغ عددها 10 فقرات على أوساط مرجحة لنظام الحوافز تقع بين 3.503 - 3.1 درجة، وأوزان مئوية تقع بين 70.06 -62 درجة، كما موضح في الجدول 7 لفين كوعليه فأن جميع هذه الفقرات اعتمدت من قبل جهاز الارشاد

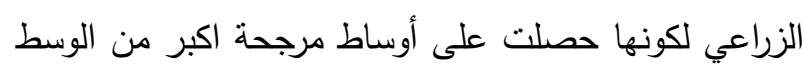

$$
\text { الفرضي للمقياس البالغ } 3 \text { درجات. }
$$

وبصدد ترتيب الفقرات المتعلقة بمحور (الوصف الوظيفي) يتضح من الجدول 6 ثقارب بين الأوساط المرجحة للفقرات المتعلقة بهذا المحور، ومع ذلك جاءت فقرة (يعرف كل موظف في جهاز الأششاد الزراعي واجباته ومسؤولياته في اداء عمله ) بالتزتيب الأول بوسط مرجح 3.581 درجة،

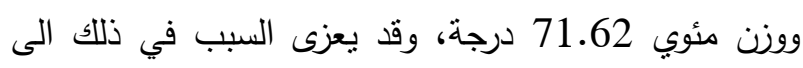

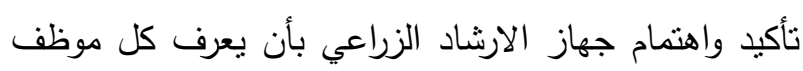

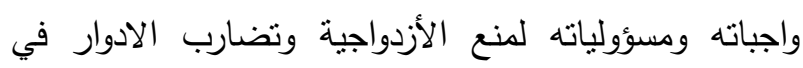

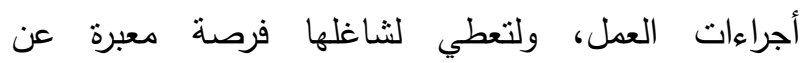
الأستقلالية وحرية التصرف حول أسلوب أداء العمل، ولأتاحة الفرصة له، في التفكير والعمل بشكل مستقل عن غيره حتى وحيه

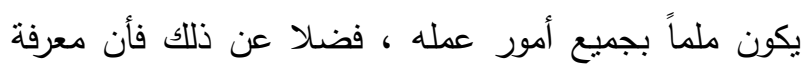

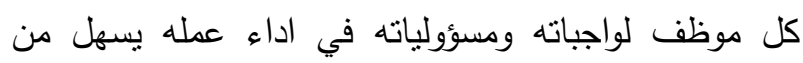

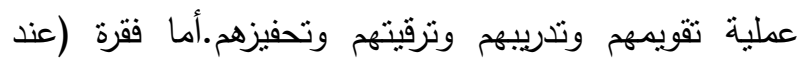


جدول 7. توزيع المبحوثين وفقاً لفقرات محور نظام الحوافز

\begin{tabular}{|c|c|c|c|c|}
\hline الترتيب & 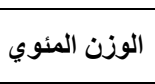 & 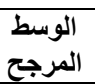 & الفقرات & 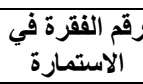 \\
\hline 1 & 70.06 & 3.503 & تمنح الدائرة كتب شكر وشهادات التقدير للمبدعين من الموظفين في الأرشاد الزراعي . & 2 \\
\hline 2 & 68.78 & 3.439 & يعاقب الموظف بحجم الخطأ الذي ارتكبه . & 8 \\
\hline 3 & 68.16 & 3.408 & يعاقب الموظف (خصم من راتبه اوتوجيه تنبيه أو انذار اليه )وفق الضوابط والتعليمات عند & 7 \\
\hline 4 & 67.56 & 3.378 & تمنح الدائرة تعويض مادي للموظفين في الأرشاد الزراعي الذين يعملون في القرى النائية . & 3 \\
\hline 5 & 66.62 & 3.331 & تعتمد الأدارة معايير عادلة وموضوعية في اجراءات ترقيةّ الموظفين في & 4 \\
\hline 6 & 66.36 & 3.318 & توجد مكافأة تثجيعية للأداء المتفوق لَلموظفين الذين يجيدون الانجاًز في وظائفهم . " & 1 \\
\hline 7 & 64.44 & 3.222 & يعاقب الموظف وقت حدوث الخطأ مباشرة . & 9 \\
\hline 8 & 64.2 & 3.210 & 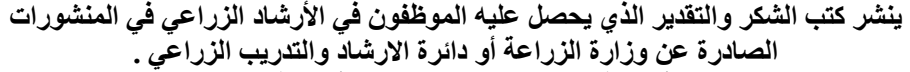 & 5 \\
\hline 9 & 63.42 & 3.171 & يكلف الموظف بمهمات أضافية لعمله الحالي مقابل اجور أضافية اعترافا من الادارة بقدراته & 6 \\
\hline 10 & 62 & 3.1 & ان المكافأة التي يتقاضاها العاملون في الأرشاد عادلة وتتناسب مع متطلبات الاعمال التي & 10 \\
\hline
\end{tabular}

3درجات.وبصدد نرتيب الفقرات المتعلقة بمحور (تدريب وتطوير العاملين) يتضح من الجدول 8 نقارب بين الأوساط

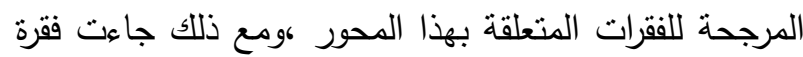
(يوجه التدريب والتطوير الى كافة العاملين في جهاز الأرشاد الزراعي) بالترتيب الاول بوسط مرجح 3.745 درجة، ووزن الته مئوي 74.9 درجة وقد يعزى السبب في ذللك الى اهتمام جهاز الارشاد الزراعي بعملية التدريب ، واعطاء فرصة لهري

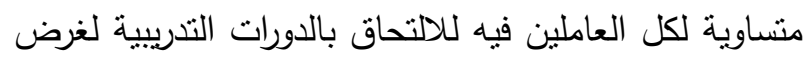
زيادة معارفهم ومهاراتهم في مجال عملهم ولمواكبتهم بلهانه

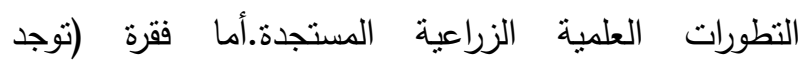
تخصيصات مالية كافية لتدريب الموظفين في جهاز الأرشاد التراتية الزراعي) فقد جاءت بالمرنبة الأخيرة بوسط مرجح 3.01 درجة، ووزن مئوي 60.2 درجة، وقد يعزى السبب في ذللك الى قلة التخصيصات المالية المخصصة لتدريب الموظفين

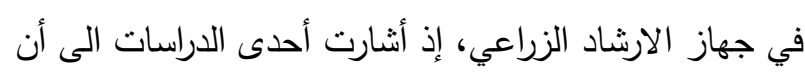

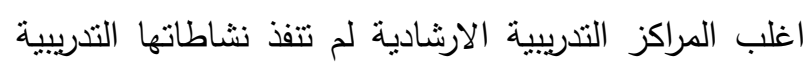

\section{لعدم وجود تخصيصات مالية كافية لنتفيذها9.}

5-محور تقويم اداء العاملين حصلت الفقرات المتعلقة

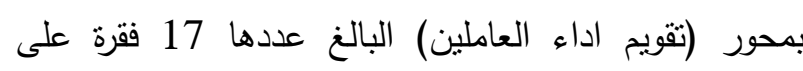

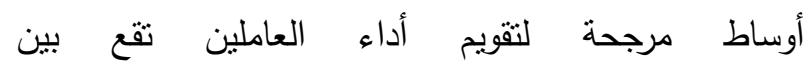

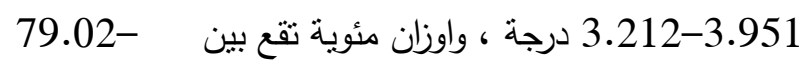

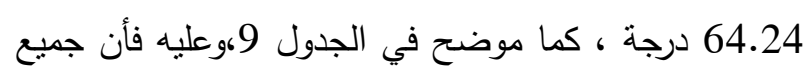
هذه الفقرات اعتددت من قبل جهاز الارشاد الزراعي لكونها

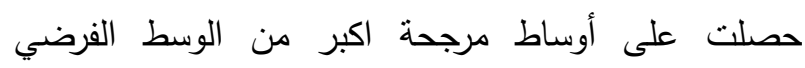

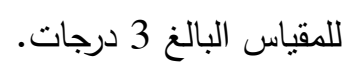

وبصدد ترتيب الفقرات المتعلقة بمحور (نظام الحوافز) يتضح من الجدول 7 نقارب بين الأوساط المرجحة للفقرات المتعلقة

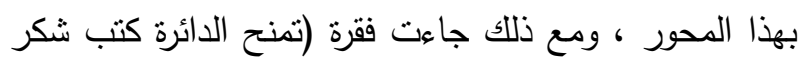
وشهادات التقدير للمبدعين من الموظفين في الأرشاد الزراعي) بالترتيب الاول بوسط مرجح 3.503 درجة، ووزن فئن

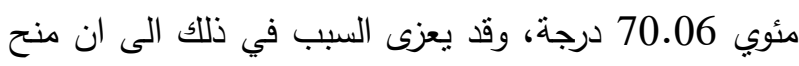
كتب الثكر وشهادات التقدير للموظفين تعد احد الحوافز المعنوية التي تزيد من حماس الموظفين ودافعيتهم للعمل ، كما وتناعد على شعور الموظف بالتقدير والفخر امام زملائه

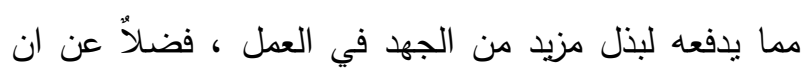

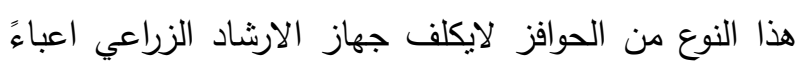

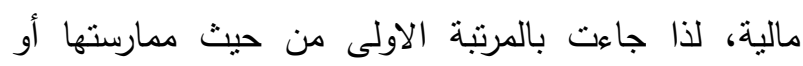
اعتمادها في جهاز الارشاد الزراعي. اما فقرة (أن المكافأة

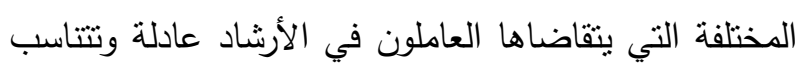
مع متطلبات الأعمال التي يقوم بها العاملون في هذا الجهاز )

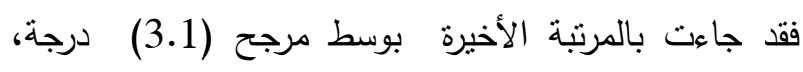

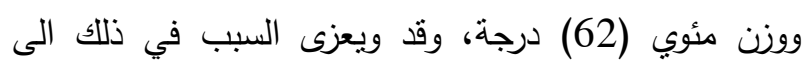
ضعف دور جهاز الارشاد الزراعي في منح المكافأة الى دمانى

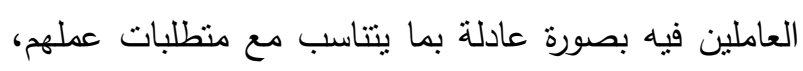
فضلا عن الجوانب الثخصية والمحسوبية والمنسوبية. 4- محور تدريب وتطوير العاملين حصلت الفقرات المتعلقة بمحور (تدريب وتطوير العاملين) البالغ عددها 22 فقرة على ونى أوساط مرجحة لتدريب وتطوير العاملين تقع بين -3.01

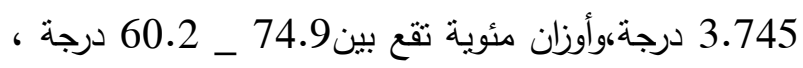
كما موضح في الجدول 8،وعليه فأن جميع هذه الفقرات

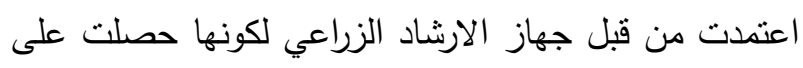

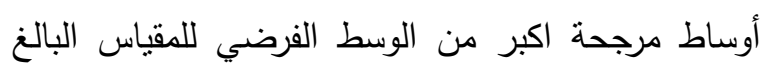


جدول 8.توزيع المبحوثين وفقاً لفقرات محور تدريب وتطوير العاملين

\begin{tabular}{|c|c|c|c|c|}
\hline 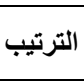 & 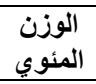 & 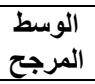 & الفقرات & رقم الاستمارة في \\
\hline 1 & 74.9 & 3.745 & يوجه التدريب والتطوير الى كافة العاملين في جهاز الارش & 1 \\
\hline 2 & 74.62 & 3.731 & الماضاءة والمقاعد وغيرها. & 17 \\
\hline 3 & 73.98 & 3.699 & تنفذ البرامج التدريبية للموظفين في الارشاد الزراعي وفق خطة معدة مسبقـا . & 14 \\
\hline 4 & 73.5 & 3.675 & تستخدم اساليب تدريبية متتوعة لاثارة دافُقعية المتدربين (ألموظفين ) & 15 \\
\hline 5 & 72.44 & 3.622 & 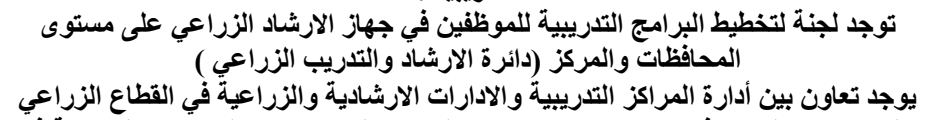 & 7 \\
\hline 6 & 71.54 & 3.577 & 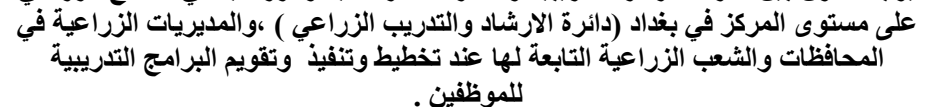 & 9 \\
\hline 7 & 71.22 & 3.561 & توجد عملية تقويم دوري لعملية التتريب اثناء أجراء هذه العملية . & 16 \\
\hline 8 & 70.38 & 3.519 & 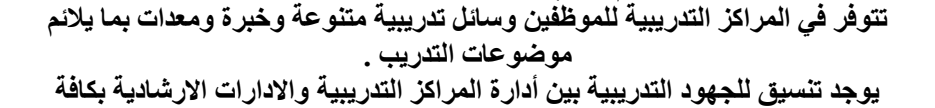 & 18 \\
\hline 9 & 69.38 & 3.469 & 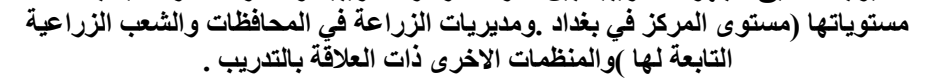 & 8 \\
\hline 10 & 68.46 & 3.423 & توجد عملية تقويم للبرامج التدريبية بعد انتهائها للتأكد من جودتها . & 21 \\
\hline 11 & 67.22 & 3.361 & تتم مكافأة المدربين المتميزين عذد أقامة البرامج التدريبية & 20 \\
\hline 12 & 66.34 & 3.317 & تعبر محتوى المادة التدريبية عن الحاجات التدريبية للمتّربين (الموظفين ). & 13 \\
\hline 13 & 66.02 & 3.301 & تتم مكافاة المتدربين الذين يحققون نتائج ايجابية جراء التدريب عند العودة الى مواقع عملهم . & 19 \\
\hline 14 & 65.64 & 3.282 & اعطاء فرصة للموظفين لمناقثة حاجاتهم التدريبية مع مسؤوليهم . ـ. & 6 \\
\hline 15 & 65.1 & 3.255 & ان ادارات الارشاد الزراعي والموظفين المرشحين للتريب لديهم تصور واضح عن اهداف & 10 \\
\hline 16 & 64.62 & 3.231 & يتم ترشيح الموظفين للألتحاق بالدورات ألتدريبية في ضوء حاجاتهم للتدريب . & 3 \\
\hline 17 & 63.68 & 3.184 & توجد عملية متابعة وتقويم لاداء الموظفين بعد انتهاء عملية تدريبهم . & 22 \\
\hline 18 & 63.04 & 3.152 & غياب الكوادر المؤهلة علميا لتحديد الحاجات التدريبية للموظفين . & 5 \\
\hline 19 & 62.02 & 3.101 & تحدد الحاجات التدريبية للموظفين بالأساليب العلمية (كالمقابلات والاستبيانات ،الملاحظة) & 4 \\
\hline $\begin{array}{l}20 \\
21\end{array}$ & $\begin{array}{l}61.74 \\
61.28\end{array}$ & $\begin{array}{l}3.087 \\
3.064\end{array}$ & 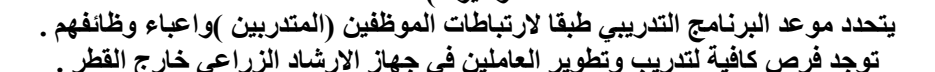 & $\begin{array}{c}12 \\
2\end{array}$ \\
\hline 22 & 60.2 & 3.01 & توجد تخصيصات مالية كافية لتذريب الموظفين في جهازّ & 11 \\
\hline
\end{tabular}

جدول 9. توزيع المبحوثين وفقاً لققرات محور تقويم

\begin{tabular}{|c|c|c|c|c|}
\hline 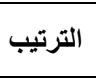 & 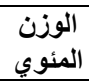 & 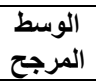 & الفقرات & في الاستمارة \\
\hline 1 & 79.02 & 3.951 & تعد تقارير عن تقدير اداء العاملين في جهاز الارشاد من قبل مسؤولهم او رؤوسائهم المباشرين . & 9 \\
\hline 2 & 78.78 & 3.939 & يتم تقويم اداء العاملين في جهاز الارشاد الزراعي من قبل رؤوسائهماومسؤولهم المباشرين. & 7 \\
\hline 3,5 & 77.46 & 3.873 & يتحسن اداء الموظف في جهاز الارشاد الزراعي بعا نو اقصه & 14 \\
\hline 3,5 & $\mathbf{7 7 . 4 6}$ & 3.873 & توثث نتائج تقويم اداء العاملين في جهاز الارشاد الزراعي للرجوع اليها بشكل سهل عند الحاجة . & 13 \\
\hline 5 & 77.22 & 3.861 & توجد اهداف واضحة ومحددة تستند عليها عملية تقويم اداء العاملين في جهاز الارشاد الزراعي . & 1 \\
\hline 6 & 71.98 & 3.599 & أن نتائج التقويم هي الاساس في منح العاملين المكافئاتَ المالية & 16 \\
\hline 7 & 71.62 & 3.581 & 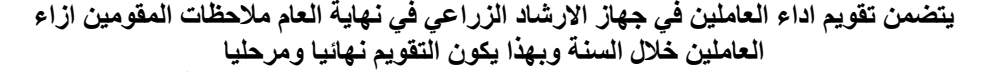 & 10 \\
\hline 8 & 71.5 & 3.575 & 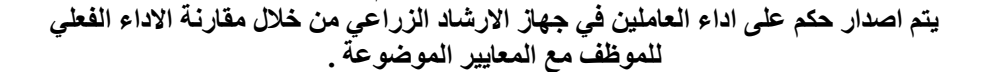 & 8 \\
\hline 9 & 70.9 & 3.545 & أن نتائج التقويم هي الاساس في ترق & 15 \\
\hline 10 & 67.42 & $\mathbf{3 . 3 7 1}$ & تتوفز الخبرة والمعرفة الكافية لدى المدراء والرؤوساء & 4 \\
\hline 11 & 67.26 & 3.363 & يتم مراجعة وتحديث المعايير بشكل دوري وتحديثها . & 17 \\
\hline 12 & 67.14 & 3.357 & 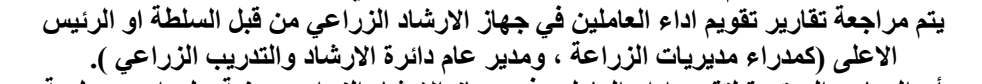 & 11 \\
\hline 13 & 66.38 & 3.319 & أن المعايير المعتمدة لتقويم اداء العاملين في جهاز الارشاد الزراعي مبنية على اسس علمية & 2 \\
\hline 14 & 65.06 & 3.253 & يتم تدريب المدراء او المسؤولين عن تقويم اداء العاملين في جهاز الارشاد الزراعي على اجراءات التوات & 6 \\
\hline 15 & 64.64 & 3.232 & تعتمد اكثر من طريقة لتقويم اداء العاملين في جهاز الارشاد الزراعي . & 5 \\
\hline 16 & 64.48 & 3.224 & يتم تقويم اداء العاملين في جهاز الارشاد الزراعي سنويا (مرة واحدة في السنة )وبناءا على ادائهم & 3 \\
\hline 17 & 64.24 & 3.212 & يتم اطلاع العاملين في جهاز الارشاد الزراعي على نتائج تقويم ادائهم الوظيفي . & 12 \\
\hline
\end{tabular}


مئوي 64.24 درجة، وقد ويعزى السبب في ذللك الى أن أغلبية القائمين بعملية الثقويم في جهاز الارشاد الزراعي

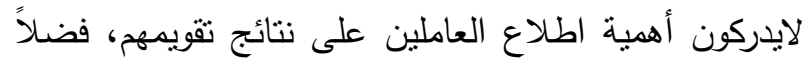
عن أعتقادهم بأن أعداد تقارير النقويم بصورة سرية تجنبهر المشكلات التي يحتمل حدوثها من قبل العاملين الذين نتائج تقويم أداؤهم ضعيف مع رؤوسائهم. 6-محور الخدمات المقدمة للعاملين:حصلت الفقرات المتعلقة بمحور (الخدمات المقدمة للعاملين) البالغ عددها 12 فقرة على اوساط مرجحة للخدمات المقدمة للعاملين يقع بين

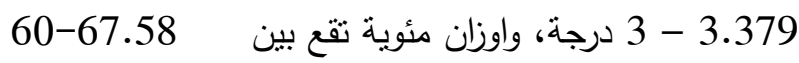
درجة، كما موضح في الجدول 10،وعليه فأن جميع هذه الفقرات اعتمدت من قبل جهاز الارشاد الزراعي لكونها هوديه

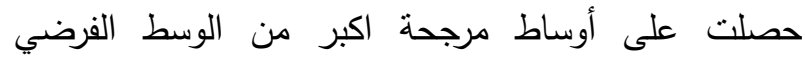

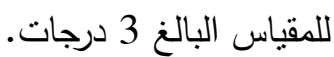

وبصدد ترتيب الفقرات المتعلقة بمحور (تقويم اداء العاملين) يتضح من الجدول 9 ثقارب بين الاوساط المرجحة للفقرات

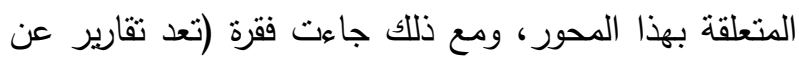

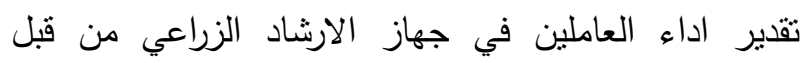
مسؤولهم اورؤوسائهم المباشرين) بالترتيب الاول بوسط مرجح

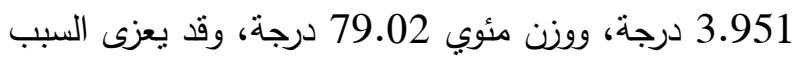
في ذلك الى اهتمام المدراء او الرؤوساء المباشرين في جهاز الارشاد الزراعي بأعداد ثقارير عن اداء موظفيهه لكونه الاسلوب الثائع للكثف عن مدى كفاءة الموظفين في أدئهم لأعمالهم في ضوء معايير ومقتضيات هذا الأداء، الى جانب

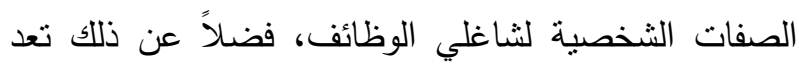

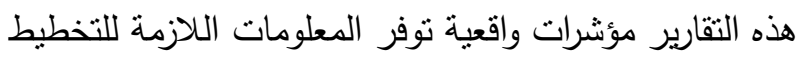
للموارد البشرية، ولتحديد حاجاتهم التدريبية والعلاوات والمكافأة

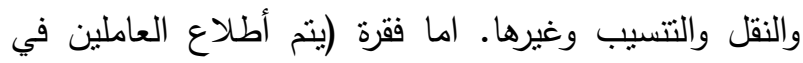
جهاز الأرشاد الزراعي على نتائج تقويم ادائهم الوظيفي) فقد ولدي

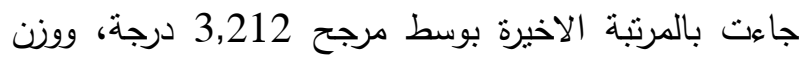

جدول 10. توزيع المبحوثين وفقاً لفقرات محور الخدمات المقدمة للعاملين

\begin{tabular}{|c|c|c|c|c|}
\hline الترتيب & 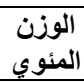 & 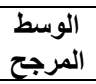 & الفقرات & رقا الاستمارة في \\
\hline 1 & 67.58 & 3.379 & توجد وسائل لنقل العاملين في جهاز الأرشاد الزراعي من مكان أقامتهم الى مواقع عملهم وبالعكس & 3 \\
\hline 2 & 67.22 & 3.361 & تسمح الدائرة للموظفين التفرغ للاراسة لعدد من السنوات بأجر كامل اوجزئي . & 11 \\
\hline 3 & 65.66 & 3.283 & توجد مكتبة في الدائرة تحوي كتبا متخصصة في مجال الزراعة والارشاد & 5 \\
\hline 4 & 64.92 & 3.246 & توجد مكتبة في الدائرة تحوي كتبا عامه . & 4 \\
\hline 5 & 64.36 & 3.218 & 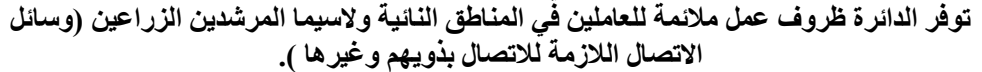 & 7 \\
\hline 6 & 63.68 & 3.184 & توجد حضانة لاطفال الموظفين قريبة من موقع عملهم . & 9 \\
\hline 7 & 63.32 & 3.166 & توجد روضة لاطفال الموظفين قريبة من مواقع عملهم . & 10 \\
\hline 8 & 62.02 & 3.101 & توفر الدائرة السكن الملاثم للعاملين في المناطق النائية ولاسيما المرشدين الزراعين . & 6 \\
\hline 9 & 61.6 & 3.080 & توفر الدائرة برامج ترفيهية واجتماعية للعاملين فيها . & 1 \\
\hline 10 & 60.42 & 3.021 & توفر الدائرة خدمات طبية وصحية للعاملين فيها مجانا او بأسعار رمزية . & 2 \\
\hline 11 & 60.2 & 3.01 & توجد مطاعم واستراحات لتقديم الطعام للعاملين وبأسعار منخفضة & 8 \\
\hline 12 & 60 & 3 & توفر دوائر الارشاد الزراعي للعاملين فيها سفرات سياحية. & 12 \\
\hline
\end{tabular}

دور جهاز الارشاد الزراعي في اقامة سفرات سياحية داخلية

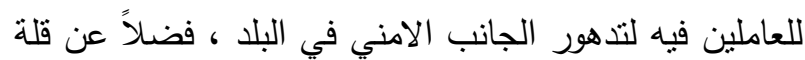

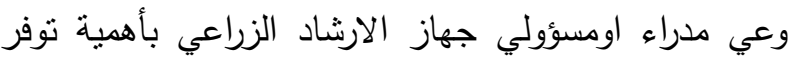

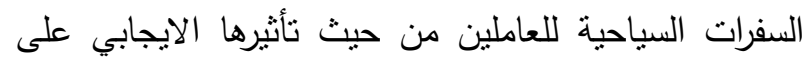

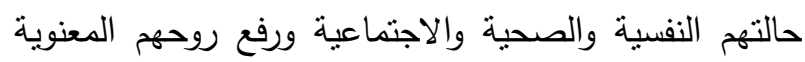
وزيادة حماسهم واندفاعهم نحو أنجاز اعمالهم. 7-محور علاقات العمل بين العاملين:حصلت الفقرات المتعلقة بمحور (علاقات العمل بين العاملين)البالغ عددها (10) فقرات على أوساط مرجحة لعلاقات العمل بين العاملين يقع بين 368.168-3.933 درجة، وأوزان مئوية تقع بين 83.36- 78.66 درجة، كما موضح في الجدول
وبصدد ترتيب الفقرات المتعلقة بمحور (الخدمات المقدمة للعاملين) يتضح من الجدول 10 تقارب بين الاوساط المرجحة للفقرات المتعلقة بهذا المحور ، ومع ذلك جاءت فقرة لبهن (توجد وسائل لنقل العاملين في جهاز الارشاد الزراعي من مكان اقامتهم الى مواقع عملهم وبالعكس) بالترتيب الاول بوسط مرجح 3.379 درجة،ووزن مئوي 67.58 درجه، وقد يعزى السبب في ذلك لضمان وصول الموظفين الى دوائرهم

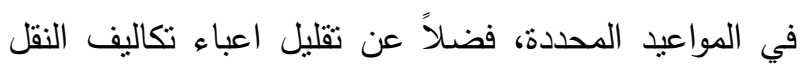

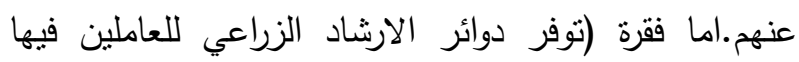

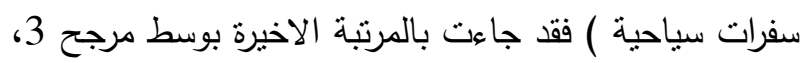

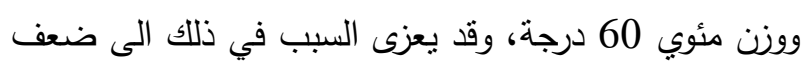


11،وعليه فأن جميع هذه الفقرات اعتمدت من قبل جهاز الوسط الفرضي للمقياس البالغ 3 درجات.

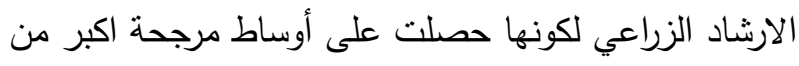

جدول 11:توزيع المبحوثين وفقاً لفقرات محور علاقات العمل بين العاملين

\begin{tabular}{|c|c|c|c|c|}
\hline الترتيب & 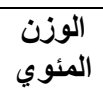 & 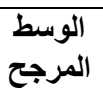 & الفقرات & رقاسم الفقرة في \\
\hline 1 & 83.36 & 4.168 & تسود بيئة العمل علاقات وديةة بين الموظفين ومدرائهماورؤسائهر . & 1 \\
\hline 2 & 82.52 & 4.126 & 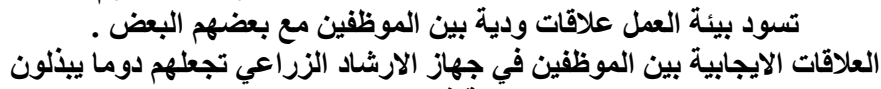 & 2 \\
\hline 3 & 82.3 & 4.120 & 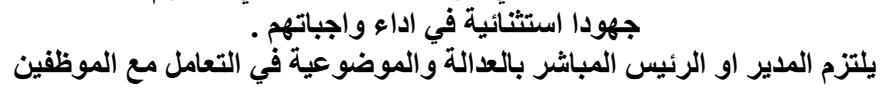 & 10 \\
\hline 4,5 & 82.28 & 4.114 & توجد فرصة لموظفي جهاز الارشاد الزراعي الأتصال بمدرائهم او مسؤولهم & 6 \\
\hline 4,5 & 82.28 & 4.114 & اومعاونيهم مباشرة للتُعبير عن ارائهم عند التُعرض لمشكلات اوغبن في العمل & 3 \\
\hline 6,5 & 81.68 & 4.084 & يلتزم الموظفون في جهاز الارشاد الزراعي بأوامروتوجيهات الادارة . & 9 \\
\hline 6,5 & 81.68 & 4.084 & 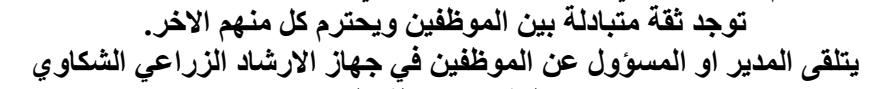 & 7 \\
\hline 8 & 80.72 & 4.036 & وجود التعاون والمساعدة بين الموظفين في جهاز الارشاد الزراعي عن حاجة . & 4 \\
\hline 9 & 80.36 & 4.018 & يشجع الموظفون في جهاز الارشاد الزَراعي كل منهم للاخر في تقديم الافكار & 5 \\
\hline 10 & 78.66 & 3.933 & الجديدة التي تسهه في تحقيق اهداف الارشاد الزراعي . & 8 \\
\hline
\end{tabular}

بصدد ترتيب الفقرات المتعلقة بمحور (علاقات العمل بين جهاز الارشاد الزراعي كل منهم للاخر في تقديم الافكار الجديدة التي تسهم في تحقيق اهداف الارشاد الزراعي) فقد العاملين)يتضح من الجدول 11تقارب بين الاوساط المرجحة جاءت بالمرنبة الاخيرة بوسط مرجح 3.933 درجة، ووزن للفقرات المتعلقة بهذا المحور ،ومع ذلك جاءت فقرة (تسود مئوي 78.66 درجة وقد يعزى السبب في ذلك قلة اهتمام بيئة العمل علاقات ودية بين الموظفين ومدرائهم او رؤسائهم) العاملين في جهاز الارشاد الزراعي في تقديم الافكار الجديدة بالترتيب الاول بوسط مرجح 4.168 درجة،ووزن مئوي 83.36 درجة، وقد يعزى السبب في ذلك الى اهتمام أدارات

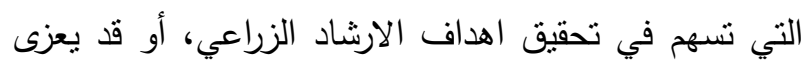
جهاز الارشاد الزراعي بتكوين علاقات جيدة مع مرؤوسيهم

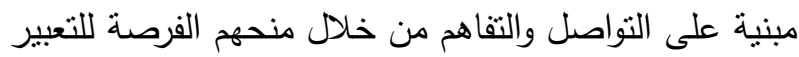
عن أفكارهم وأرائهم ومشاركتهم في اتخاذ القرارات المتعلقة

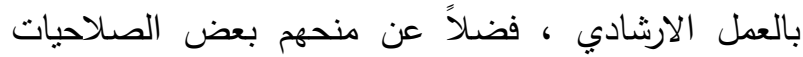
ترتيب محاور بعض المهام التخصصية لأدارة الموارد البشرية

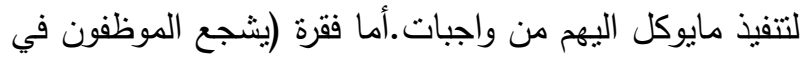
في جهاز الارشاد الزراعي والبالغ عددها 7 محاور .

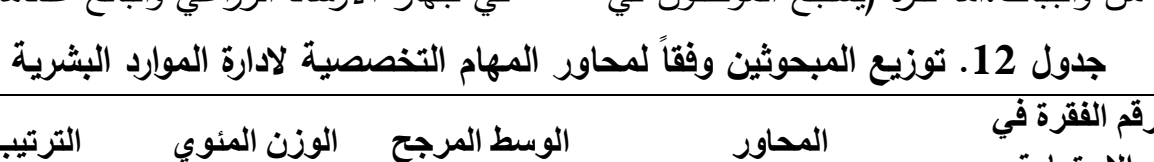

\begin{tabular}{|c|c|c|c|c|}
\hline الترتيب & الوزن المئوي & الوسط المرجح & المحاور & رقم الفقرة في \\
\hline 1 & 81.594 & 4.080 & علاقات العمل بين العاملين & 7 \\
\hline 2 & 70.739 & 3.538 & تقويم اداء العاملين & 5 \\
\hline 3 & 70.578 & 3.529 & التخطيط للموارد البشرية . & 1 \\
\hline 4 & 67.605 & 3.380 & تدريب وتطوير العاملين . & 4 \\
\hline 5 & 66.16 & 3.308 & نظام الحوافز. & 3 \\
\hline 6 & 65.702 & 3.288 & الوصف الوظيفي . & 2 \\
\hline 7 & 63.415 & 3.171 & الخدمات المقدمة للعاملين . & 6 \\
\hline
\end{tabular}

يتضح من الجدول 12 حصول جميع هذه المحاور على أوساط مرجحة لدرجات موافقة اكبر من الوسط الفرضي لدرجات مقياس واقع بعض المهام التخصصية لادارة الموارد البشرية المستخدم في البحث والبالغ 3 درجات، وعليه فأن
جميع هذه المحاور أعتمدت من قبل جهاز الارشاد الزراعي

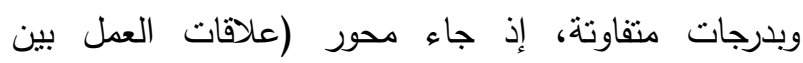
العاملين) بالترتيب الاول بوسط مرجح 4.080 درجة، ووزن إهن مئوي 81.594 درجة، وقد يعزى السبب في ذلك الى اهتمام 
جهاز الارشاد الزراعي على أقامة علاقات أنسانية بين العاملين مبنية على حسن المعاملة والاحترام المنبادل بين العاملين أنفسهم وبينهم وبين رئيسهم المباشر لأهميتها في استثارة وزيادة اندفاعهم نحو أنجاز الاعمال والمهام الموكلة ولئة

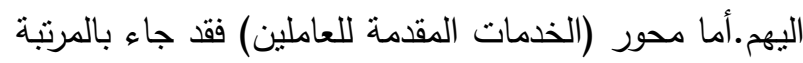
الاخيرة بوسط مرجح 3.171 درجة، ووزن مئوي 63.415 درجة، وقد يعزى السبب في ذلك الى ضعف أمكانية جهاز الارشاد الزراعي في توفير الخدمات للعاملين فيه ولربما بسبب قلة التخصيصات المالية نتيجة لتعرض البلد الى ازمة فئرة مالية في السنوات الاخيرة. في ضوء نتائج البحث بستتنج وجود أهنمام من قبل جهاز الارشاد الزراعي في تطبيق جميع

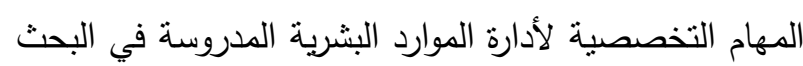

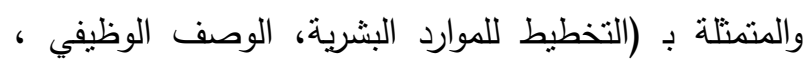

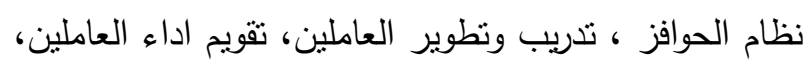
الخدمات المقدمة للعاملين، وعلاقات العمل بين العاملين) ولكن بدرجات متفاوتة.كذلك وجود أهتمام بدرجة كبيرة جداً من قبل جهاز الارشاد الزراعي في تطبيق وظيفة علاقات بلتهات

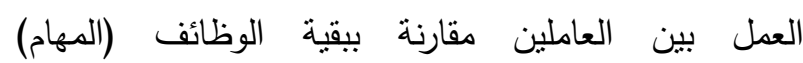
التخصصية لادارة الموارد البشرية، وهذا يعني أن المسؤولين

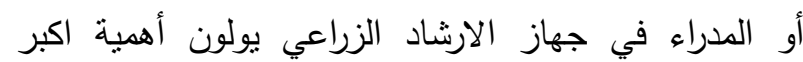
لجانب علاقات العمل بين العاملين في أدارتهم للموارد البشرية.كما بتمتع جهاز الارشاد الزراعي بدرجة كبيرة في تطبيق وظيفتي تقويم اداء العاملين، وتخطيط الموارد البشرية. كذلك نستتتج أن جهاز الإرشاد الزراعي بحاجة الى أهتمام

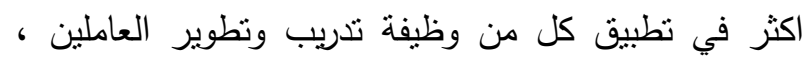

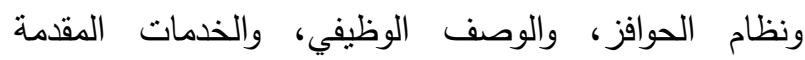

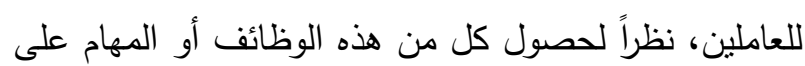
درجات تطبيق دون المستوى المطلوب ولاسيما وظيفة الخدمات المقدمة للعاملين .في ضوء النتائج والأستتناجات

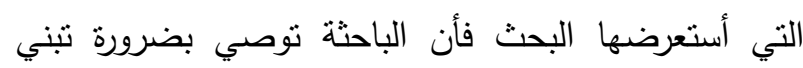
نتائج هذا البحث من قبل جهاز الارشاد الزراعي من أجل

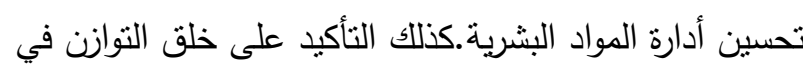
التطبيث بين الوظائف أو المهام التخصصية لادارة الموارد

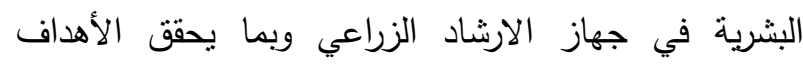

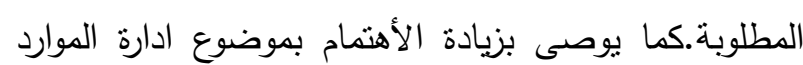

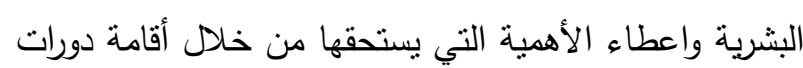

تدريبية لمدراء الارشاد الزراعي وعلى كافة المسنويات الادارية في مجال أدارة الموارد البشرية وبأثراف كادر أكاديمي متخصص ليصبحوا على مسنوى يؤهلهم للقيام بهذه العملية

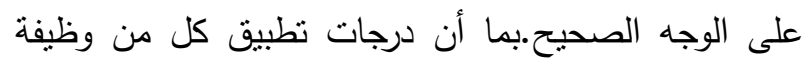

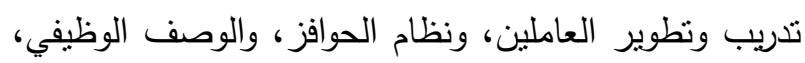

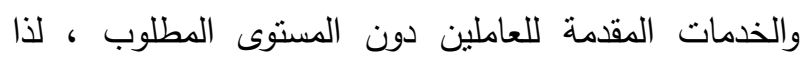
توصي الباحثة بالأتي: أ-ضرورة زيادة أهتمام جهاز الارشاد الزراعي بعملية تدريب

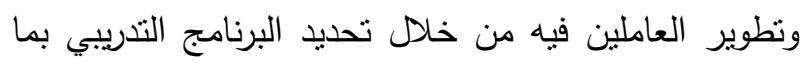
يتلائم وحاجة أختصاصات العاملين للتدريب، وزيادة توفير

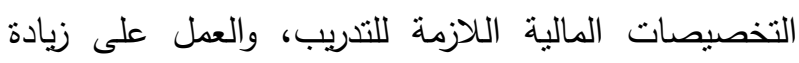
فرص التدريب من خلال مفاتحة المراكز والهيئات المتخصصة سواء داخل أو خارج البلا.

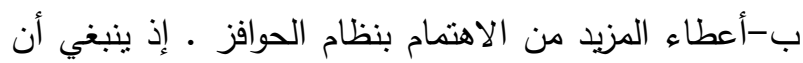

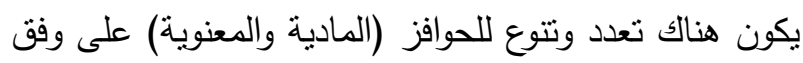
حاجات ودوافع العاملين في جهاز الارشاد الزراعي، فضلاً

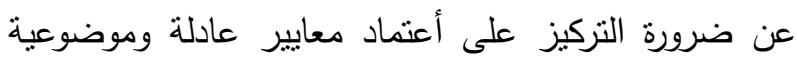
لمنحها. ج-ضرورة زيادة أهتمام جهاز الارشاد الزراعي بوظيفة

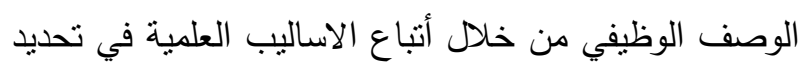
الوصف الوظيفي لكل وظيفة في جهاز الارشاد الزراعي من حيث تحديد واجبات ومسؤوليات كل وظيفة والمؤهلات المطلوبة لشاغلي كل وظيفة، ومراعاة تحديد ظروف العمل

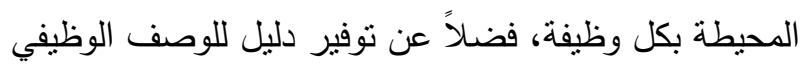

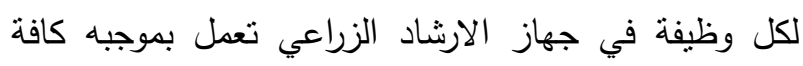
وحدات الارشاد الزراعي وعلى مختلف المستويات (المركز

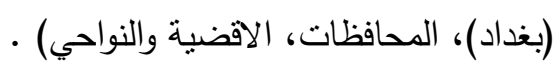
د-على جهاز الارشاد الزراعي اعطاء المزيد من الاهتمام

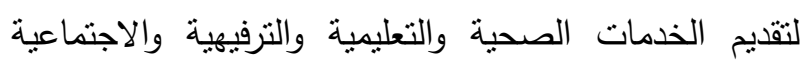
وغيرها للعاملين وذلك من خلال زيادة التخصصات المالية لمجال الخدمات ، وضرورة قيام الأدارة العليا في جهاز الارشاد الزراعي بتشكيل لجان متخصصة مهنتها متابعة

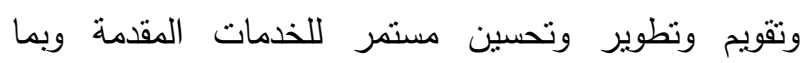
ينعكس على رضا العاملين، فضلاًعن زيادة نوعية مدراء

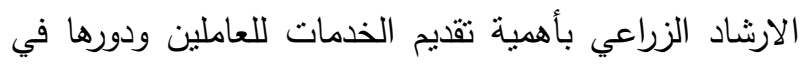
رفع روحهم المعنوية وتحسين مستوى ادائهم في العمل. 


\section{REFERENCES}

1. Ahfor professional Eduaction. WWW. akadnews.orgmed, M. M., 2014.canadion organization.

2. Abu Sharkh, N. H. A. 2010., Assess the Impact of Incentives on the level of Functionality in the Palestinian TelecommuNications company from the Perspective of Workers, unpublished Thesis, Faculty of Economics and Administrative Sciences, AlAzhar University.PP:80.

3. Abbas, W. H2014, Human Resources Management strategy the modern entrance to the sustainability of competitive advantage, $i$ 1, Dar Al-Hamed for Publishing and Distribution, Amman.PP;17.

4. Abbas, S. M. and A. H.B.A.A 2006, Human Resources Management, 3rd Floor, Dar Wael for printing and publishing, Amman, Jordan.PP;20.

5. Aghili, O. D2009, Contemporary human resources management strategic dimension, 2nd Floor, Dar Wael for publication, Amman, Jordan.PP13.

6. Atta, Ashraf al-Badri Wyman 0.2015, agricultural counselor at the Department of oblivion, cooperation newspaper, Al-Ahram Foundation.PP2.

7. Al-Nuaimi, M.A., Ammar Just Jujube 2011, The use of statistical methods in the design of scientific research, i 1, Dar Yazouri scientific publication and distribution, Jordan.PP;335.

8. Ameri, S. M.M., T. M. M.Ghalibi, 2011, The administration and business, i 3, Dar Wael for Publishing and Distribution, Amman. PP;694.

9. Dry, T.M. 2001, The level of Performance of Agricultural Extension Staff in charge of Baloaml field in Iraq, Master unpublished, of coll of Agriculture, University of Baghdad.PP;97.

10. Egyptian, A. A., 2011, The effect on the development of administrative functionality in government ministries operating in Nablus, Master unpublished, Aaguetsad College, AnNajah National University.PP;250.

11. Furaiji, A. R. H. 2010, Cognitive training needs of managers in the field of Agricultural Extension Management extension units responsible for management of the provinces in the central region, unpublished M.Sc.
Thesis, Faculty of agriculture, Jammehh Baghdad.PP;71.

12. Hamid, Said Shaaban 2006, Reference Search for: Recent Trends for Management of Human Resources, Faculty of Commerce, AlAzhar University.PP;3.

13. Hammam, Mohammed Hamid Reza Zaki and Abdul Khaliq Abu Hatab, 1989, building a measure of satisfaction from work between technicians working in service stations mechanism in Egypt, a research bulletin number (41) of agricultural research, the center of Egypt.PP;466.

14. Hussein S.M. 2010. without the years, the importance of the human element in achieving corporate objectives, (report).PP;13.

15. Hyassat, Khaled Mohammed 2004, Measuring the efficiency and effectiveness of human resource management strategy and its relationship to the institutional performance in the Jordanian press institutions from the point of view of staff, Jordan Journal of Business Administration Standards, Volume 2, Issue 4.PP;558.

16. Ismail, M. A. 2008., Concept of resource planning steps, http: //www. hrdiscussion. com/hr2137.html.PP:3.

17. Jawad, S.N and C. M Towel 2009.Reality agree human resource planning and strategic planning in the public shareholding in Jordan companies and its impact on her performance: An Empirical Study from the perspective of managers, the University of Applied Sciences, Faculty of Economics and Administrative Sciences, Journal of Business and Economics, Vol. 15, No. 78.PP;25.

18. Kader, A.A. and A. I.Abusin, 2012, The impact of the practices of Human Resource Management on the productivity of the industrial sector on the application of the Sudanese group horses companies, the Journal of Science and Technology, University of Sudan .12 folder, Issue 1PP; 141 .

19. Moon, M. C. 2005, The modernization of national agricultural extension systems, a practical guide for policy-makers in developing countries, the Food and Agriculture Organization of the United Nations, Rome.PP; 135.

20. Moussawi, R. H. A., E. A. A.,Jassim, 2012, The Reality of Human vision and its 
Future development in Iraq, Journal of Business and Economics, Vol. 1, No. 93.PP14. 21. Obeidi, B.A 2013, The role of the working environment in the promotion of job satisfaction An Empirical Study in Baghdad laboratory gases, unpublished M.Sc. Thesis, Institute of Technical Administration.PP31.

22. Reza, I.A and R.Hassouni 2015, the problems facing the guideway training centers in Iraq, from the standpoint of employees, Journal of Agricultural Science, Volume 46, Issue 4.PP;5.

23. Rudaini, K. N 2014, The Diagnosis of the Impact of the Training Strategy practices in The Performance of Organizations Application on a Sample of Inspectors general offices, unpublished M.Sc. Thesis, Faculty of Administration and Economy, Baghdad University.PP;24.

24. Shaltout, A. A. Kh., 2009, The human resources development as input strategically to maximize Alastmar in the human element, a study on the staff of the Agency in the Gaza
Strip, unpublished M.Sc. Thesis, Department of Business Administration, the Islamic University of Gaza.PP;2.

25. Tai, H. Kh. 2009, Improving the dissemination of agricultural technologies and management of valuable programs of Iraq, the Euphrates Journal of Agricultural Sciences, Vol. 37, No. 3.PP;4.

26. Towel, C and M. M Pole, 2013, The Impact of Human Resource Management Practices on the learning and growth of employees in the commercial banks of the Jordan, the Jordanian Journal of Applied Sciences, Volume 15, Issue 1.PP163.

27. Wahab, A. M. A. 2003. Human Resources Management and its importance in the development of the administration, a consultative meeting for the development of public administration and financial management, Faculty of Commerce, Ain Shams University.PP;6. 